\title{
Bifunctional copper-zinc bimetallic tungstate nanoparticles decorated reduced graphene oxide (CuZnW04/rGO) for high-performance photocatalytic and supercapacitor application
}

\section{Elumalai Dhandapani}

J.K.N arts and science

\section{Prabhu S}

\section{Periyar university}

Navaneethan Duraisamy ( $\sim$ naveennanoenergy@gmail.com )

J.K.K Nataraja college of arts and science https://orcid.org/0000-0001-7285-1742

\section{Ramesh R}

Periyar university

\section{Research Article}

Keywords: Bimetallic tungstate, Reduced graphene oxide, Photocatalysis, Supercapacitor

Posted Date: April 22nd, 2021

DOl: https://doi.org/10.21203/rs.3.rs-350051/v1

License: (c) (1) This work is licensed under a Creative Commons Attribution 4.0 International License.

Read Full License

Version of Record: A version of this preprint was published at Journal of Materials Science: Materials in Electronics on June 26th, 2021. See the published version at https://doi.org/10.1007/s10854-021-06339$\mathrm{X}$. 


\title{
Bifunctional copper-zinc bimetallic tungstate nanoparticles decorated reduced graphene oxide (CuZnWO $4 /$ rGO) for high-performance photocatalytic and supercapacitor application
}

\author{
Elumalai Dhandapani ${ }^{1}$, Prabhu $S^{2}$, Navaneethan Duraisamy ${ }^{{ }^{*}}$, Ramesh $R^{2}$ \\ ${ }^{1}$ Department of Chemistry, J.K.K. Nataraja College of Arts and Science, Komarapalayam, \\ Namakkal, Tamil Nadu, India \\ ${ }^{2}$ Department of Physics, Periyar University, Salem, Tamil Nadu, India \\ Corresponding Author Email:naveennanoenergy@gmail.com
}

\begin{abstract}
In the present work, an attempt to synthesis of bimetallic copper zinc tungstate $\left(\mathrm{CuZnWO}_{4}\right)$ nanoparticles with reduced graphene oxide $(\mathrm{CuZnWO} / \mathrm{rGO})$ via one-step hydrothermal technique. The synthesized $\mathrm{CuZnWO}_{4} / \mathrm{rGO}$ composite are characterized by Fourier transform infrared spectroscopy (FTIR), Powder X-ray diffraction (XRD), scanning electron microscopy (SEM), UV-Vis diffuse reflectance spectroscopy (UV-DRS) and Photoluminescence (PL). The photocatalytic performance is examined by the degradation of methylene blue (MB) dye under visible-light irradiation. The MB dye isalmost $73 \%$ degraded within 80 minutes. Further, the electrochemical performance of hybrid $\mathrm{CuZnWO}_{4}-\mathrm{rGOcomposite}$ showed the specific capacity (SC) of $480 \mathrm{Fg}^{-1}$ at $4 \mathrm{Ag}^{-1}$ in $6 \mathrm{M} \mathrm{KOH}$ electrolyte with excellent cyclabilityconserving a capacitance retention of $127 \%$ after 5000 cycles due to increase diffusion of electrolyte ions to the electrode materials. These results support that the hybrid $\mathrm{CuZnWO}_{4}-$ rGO composite as an appropriate electrode material for high-performance SCs electrode and an auspicious catalyst for the degradation of dye (organic) contaminants in aqueous media.
\end{abstract}

Keywords: Bimetallic tungstate;Reduced graphene oxide;Photocatalysis; Supercapacitor 


\section{Introduction}

In the $21^{\text {st }}$ century, the manhood met massive challenges in energy crisis and ecological pollution. Owing to the increasing human population and industrialization, fossil fuels and coal are highly utilized and depleted very soon. The environmental problems accompanying with direct release of harmful organic pollutants from the textile industry to water sources are a serious issue[1-3]. Therefore, the investigation of fast and effective ecological protection and energy storage technologies has become a hottest theme for researchers. Generally various kinds of materials are used as a catalyst for photocatalytic activity and electrodes for energy storage device (such as metal oxides, conducting polymers, carbonaceous materials, metal sulfides and etc.,) [4-7]. Regrettably, most of the catalysts and electrodes suffer from low-light energy garnering and quick extermination of electron-hole pairs. Among these materials, the metal tungstate's has a significant consideration owing to their immeasurably wide-range of applications in various fields such as supercapacitors (SCs), photocatalysis, optical devices, structural, electrical/electronics, humidity sensors, metal-ion batteries and electrocatalysis[8,9].

Chemical contaminants such as dyes emitted from the clothing, food, and leather industries pose a major environmental threat. Photocatalytic nanomaterials are the most effective agents for the degradation of toxic organic dyes, such as methylene blue (MB), rhodamine-B (RhB) and methyl orange (MO). Due to the extreme huge release from different factories, it causes significant adverse effects on the environment and critically increases water contamination, thus effectively disrupts the ecosystem[10]. Zinc tungstate $\left(\mathrm{ZnWO}_{4}\right)$, a typical traditional catalyst, has been extensively used as photo-catalyst and applied in photocatalytic degradation of dyes (organic contaminants) due to its extraordinary aspects of cost effectiveness, high stability, non-toxicity, high quantum yield, commercial accessibility and outstanding photoelectrical performance. However, the pure $\mathrm{ZnWO}_{4}$ shows feeblish visible-light photocatalytic activity due to the wide range of band gap.

Electrochemical capacitors or supercapacitors (SCs) are a new class of electric energy storage devices, they get more consideration due to its extraordinary properties such as high cyclability, high power/energy density, and they could rapidly deliver greater energy-density than conversional capacitors and simultaneously larger power density than secondary batteries[13]. The performance of SCs is based on the electrodes, so it plays a major role in SCs. Nowadays various kinds of materials are used as a SCs electrode they are carbonaceous materials 
(such as: activate carbon, graphene, carbon quantum dots, carbon nano tubes and etc.) metal oxides (MOs) (such as: $\mathrm{NiO}, \mathrm{V}_{2} \mathrm{O}_{5}, \mathrm{Fe}_{2} \mathrm{O}_{3}$. $\mathrm{CuO}$ and etc.) and conducting polymers (CPs) (such as: polyaniline, polypyrrole, polyindole, polythiophene and etc.) [14]. The major disadvantage of the SCs is low energy density, where does not meet the future demand of portable electrical/electronic devices and modern electric vehicles [15]. Similarly, the commercializing of SCs is still stuck by the moderately poor-overall performance, like the carbonaceous materials show low specific capacitance (Cs), low conductivity of MOs as well as poor cyclability of conducting polymers (CPs).The current research is fully focused on the synthesis of novel/ hybrid nano-structured electrode materials to enhance the energy density of SCs. Among the various electrode materials, the metal tungstate's $\left(\mathrm{MWO}_{4} ; \mathrm{M}=\mathrm{Ni}, \mathrm{Cu}, \mathrm{Pb}, \mathrm{Mn}, \mathrm{Co}, \mathrm{Zn}\right.$ and etc.) are recognized as effective resources consuming adaptable chemical properties. The $\mathrm{MWO}_{4}$ attract more attention in past few decays owing to its astonishing physio-chemical assets which makes them it as a potential and auspicious materials for various applications in the arena of photocatalytic activity, energy storage, electrical/electronics, antimicrobial, magnetic, electrocatalysis, and ceramics [16,17].

In this present work, a copper zinc bimetallic tungstate $\left(\mathrm{CuZnWO}_{4}\right)$ nanoparticle decorated reduced graphene oxide ( $\mathrm{rGO})\left(\mathrm{CuZnWO}_{4} / \mathrm{rGO}\right)$ nanocomposites synthesized via hydrothermal technique. As synthesized materials are used as an electrode for SCs and catalyst for photocatalytic applications. $\mathrm{CuZnWO}_{4}$ and $\mathrm{CuZnWO}_{4}-\mathrm{rGO}$ areexamined by XRD, FTIR, SEM, and optical study of UV-DRS and photoluminescence. Electrochemical behavior is investigated by cyclic voltammetry (CV), galvanic charge discharge (GCD) and impedance (EIS) in $6 \mathrm{M} \mathrm{KOH}$ aqueous electrolyte and the photocatalytic activity are evaluated by methylene blue degradation. The above results are projected that the $\mathrm{CuZnWO} / \mathrm{rGO}$ nanocomposite assist as an effective electrode SCs electrode material for and photocatalytic applications.

\section{Experimental}

\subsection{Chemicals and materials}

Copper acetate (Sigma-Aldrich), zinc acetate (Merck), sodium tungstate (SD Fine), Cetyltrimethylammonium bromide (Sigma-Aldrich).All of the above-mentioned chemicals 
purchased were analytical grade and used without any further purification. The whole reaction was carried out using water and ethanol as solvents.

\subsection{Synthesis of $\mathrm{CuZnWO}_{4}$ and $\mathrm{CuZnWO}_{4}-\mathrm{rGO}$ Composite}

Reduced graphene oxide was synthesized by hummers method and followed by reductionusing ammonia in hydrothermal method [18]. $\mathrm{CuZnWO}_{4}$ bimetallic tungstate was synthesized by hydrothermal method using copper acetate and zinc acetate as a precursor. The precursors of copper and zinc (1;1 ratio, $0.2 \mathrm{M}$ each) and $4 \mathrm{M}$ CTAB was dissolved in $15 \mathrm{~mL}$ distilled under continues stirring for 30 minutes. Further, as prepared $0.4 \mathrm{M} \mathrm{Na} 2 \mathrm{WO}_{4} \cdot 2 \mathrm{H}_{2} \mathrm{O}$ was added drop by drop into the above solution under continuous stirring, a thick light green coloration was developed. Then the resultant solution was transferred into a $50 \mathrm{~mL}$ of Teflonlined stainless-steel autoclave and heated for $180{ }^{\circ} \mathrm{C}$ forovernightin hot air oven. The attained product was washed several times and followed by centrifuge, the obtained precipitate was dried overnight in a hot air oven at $60{ }^{\circ} \mathrm{C}$ and annealed for $450{ }^{\circ} \mathrm{C}$ at $2 \mathrm{~h}$.

A composite of $\mathrm{CuZnWO}_{4} / \mathrm{rGO}$ hybrid nanostructures was prepared using the same procedure with addition of reduced graphene oxide (rGO). Fig.1 showed the schematic illustration of $\mathrm{CuZnWO}_{4}$ and $\mathrm{CuZnWO}_{4} / \mathrm{rGO}$ composite.

\subsection{Characterization}

The crystal nature of the synthesized samples wasexamined by Powder X-ray diffraction (XRD) from the range of $2 \theta \sim 10-80, \mathrm{Ni}$ filtered $\mathrm{Cu}$ Ka radiation as a source. Fourier transform inferred spectra (FTIR) wereinvestigated using Perkin-Elmer instrument (USA) in the range of $400-400 \mathrm{~cm}^{-1}$ with KBR as a reference materialat room temperature. The surface morphology of $\mathrm{CuZnWO}_{4}$ and $\mathrm{CuZnWO}_{4}-\mathrm{rGO}$ composite were visualized by scanning electron microscope (SEM, Hitachi SU-70, Japan) running at $25 \mathrm{kV}$ an accelerating voltage. UV-visible diffuse reflectance spectra (UV-DRS) were recorded by Lambda-900 spectrometer in the range of 200$800 \mathrm{~nm}$.

\subsection{Photocatalytic activity}

The photocatalytic performance of the synthesized materials was examined against the photo-degradation of synthetic dye methylene blue (MB) under visible light at ambient temperature. Initially $100 \mathrm{mg}$ of methylene blue (MB) was added into $100 \mathrm{~mL}$ of de-ionized water and stirred well for 30 minutes. $1 \mathrm{~mL}$ of this aqueous solution was introduced into reactor 
with $50 \mathrm{mg}$ of synthesized materials at constant stirring. After that, $5 \mathrm{~mL}$ of the solution was collected with the time interval of 10 minutes up to 80 minutes. The degradation efficiency of the synthesized samples was calculated by the following equation[19].

$$
D \%=\frac{C_{0}-C_{t}}{C_{0}} \times 100
$$

Where, $\mathrm{C}_{0}$ is the major absorption intensity of $\mathrm{MB}$ dye at 0 min and $\mathrm{C}_{\mathrm{t}}$ is the dye degradation peak intensity under visible-light for the time $\mathrm{t}(10,20,30,40,50,60,70$, and $80 \mathrm{~min})$.

\subsection{Electrochemical performance}

The electrochemical performance of the synthesized electrode material was examined using a three-electrode cell in $3 \mathrm{M} \mathrm{KOH}$ aqueous electrolyte solution within the potentialwindow of $0-0.6 \mathrm{~V}$ on a biologic S-50 electrochemical workstation. Cyclic voltammogram $(\mathrm{CV})$ and galvanostatic charge and discharge (GCD) and electrochemical impedance spectra (EIS) were performed. CV was used to know the potential of the electrodes and GCD was used to examine the specific capacitance of the electrode and EIS was used to analyze the resistance of the electrode material.

\section{Results and discussion}

\subsection{X-ray diffraction analysis}

Fig. 2(a-b) illustrates the XRD spectrum of $\mathrm{CuZnWO}_{4}$ and $\mathrm{CuZnWO}_{4}-\mathrm{rGO}$ composite. Fig. 2(a) shows the XRD pattern of $\mathrm{CuZnWO}_{4}$, where indexed2 $\theta$ value of $15.47^{\circ}, 18.85^{\circ}, 23.82$ $\circ, 24.59^{\circ}, 25.84^{\circ}, 28.98^{\circ}, 30.45^{\circ}, 36.5^{\circ}, 38.5^{\circ}, 41.2^{\circ}, 44.9^{\circ}, 48.56^{\circ}, 51.6^{\circ}, 53.5^{\circ}, 61.8^{\circ}$, $62.6^{\circ}, 65.03^{\circ}$ and $68.07^{\circ}$ corresponding to (010), (100), (011), (110), (101), (111), (111), (021), (200), (102), (112), (112), (130), (202), (113), (230), (040) and (041) diffraction planes, respectively. However, some of the planes are comparative to both metals $\mathrm{Cu}$ and $\mathrm{Zn}$ in bimetallic tungstate. The XRD diffraction pattern of $\mathrm{CuZnWO}_{4}$ accord with the pristine structural phase of $\mathrm{CuWO}_{4}$ and $\mathrm{ZnWO}_{4}$ in standard JCPDS card no. 80-1918and89-7624 respectively[20,21]. The $\mathrm{CuZnWO}_{4}$-rGO nanocomposite XRD pattern is shown in Fig.2(b), where illustrates thesimilar peaks as like Fig. 2 a corresponds to $\mathrm{CuZnWO}_{4}$ but no other characteristic peaks for $\mathrm{rGO}$ is not clearly visible in $\mathrm{CuZnWO}_{4}-\mathrm{rGO} \mathrm{XRD}$ pattern, due to the shielding effect by strong diffraction peaks of $\mathrm{CuZnWO}_{4}$ particles but $\mathrm{rGO}$ peaks are merged with $\mathrm{CuZnWO}_{4}$ peaks inCuZnWO $4-\mathrm{rGO}$ composite [22,23]. 


\subsection{Fourier transform inferred spectraanalysis (FT-IR)}

FT-IR spectra areused to investigate the surface state and functional groups of theprepared samples. Fig. 3 shows, FTIR spectra of the $\mathrm{CuZnWO}_{4}$ and $\mathrm{CuZnWO}_{4} / \mathrm{rGO}$ nanocomposite. Fig. 3(a) display the FTIR spectrum of $\mathrm{CuZnWO}_{4}$, the peak at $3000-3400 \mathrm{~cm}^{-1}$ corresponds to the hydroxyl group (OH)[24], the absorption peaks at $460 \mathrm{~cm}^{-1}, 595 \mathrm{~cm}^{-1}$ and 625 $\mathrm{cm}^{-1}$ are associated with the stretching and bending vibration of $\mathrm{M}-\mathrm{O}(\mathrm{M}=\mathrm{Cu}$ and $\mathrm{Zn})$. While the band at $806 \mathrm{~cm}^{-1}$ is related to the bending/stretching vibration of $\mathrm{W}-\mathrm{O} \mathrm{cm} \mathrm{cm}^{-1}$ for tetrahedral $\mathrm{WO}_{4}[25,26]$ and the peak at $890 \mathrm{~cm}^{-1}$ is associated with the stretching/bending vibration of M-WO groups[27]. Fig. 3(b) shows the FTIR spectrum of $\mathrm{CuZnWO}_{4} / \mathrm{rGO}$ composite. The peaks which were obtained in $\mathrm{CuZnWO}_{4}$ spectra are also present in $\mathrm{CuZnWO}_{4} / \mathrm{rGO}$ composite and some other absorptionbandsare obtained with respect to $\mathrm{rGO}$ [27]. The peak at $1716 \mathrm{~cm}^{-1}$ is allocated for the $\mathrm{C}=\mathrm{C}$ skeleton of $\mathrm{rGO}[28]$. Therefore, the results shown in Fig. 3. is an evidence to confirm a synthesized product as $\mathrm{CuZnWO}_{4} / \mathrm{rGO}$ nanocomposite.

\subsection{UV-Vis DRS and Photoluminescence analysis}

The light absorption property of the synthesized samples is analyzed using UV-Vis diffuse reflection spectra. The synthesized samples (Fig. 4(a,b)) display a strong absorption in visible region owing to the bandgap transition of $\mathrm{CuZnWO}_{4}$ semiconductorindicating their probable application as photocatalysts. The $\mathrm{CuZnWO}_{4}$ shows an absorption edge at $530 \mathrm{~nm}$ and the rGO loaded $\mathrm{CuZnWO}_{4}$ shows the high absorption at $545 \mathrm{~nm}$ comparedthan $\mathrm{CuZnWO}_{4}(530$ $\mathrm{nm}$ ), The calculated band-gap energies of 2.27 and $2.18 \mathrm{eV}$, corresponding to the $\mathrm{CuZnWO}_{4}$ and $\mathrm{CuZnWO}_{4}-\mathrm{rGO}$, respectively. It clearly shows the $\mathrm{CuZnWO}_{4}-\mathrm{rGO}$ composite parades high catalytic activity than $\mathrm{CuZnWO}_{4}$ under visible light due to the lowest band-gap of $2.18 \mathrm{eV}$. The trapping and recombination of electron holes is playing a vital role in photocatalytic activity, where analyzed by photoluminescence spectra in Fig. 4(d). The PL spectra of $\mathrm{CuZnWO}_{4}$ and $\mathrm{CuZnWO}_{4}$-rGO are shown in Fig.4(d). it possesses a green-blue spectrum with an extreme intensity at $411 \mathrm{~nm}$ and $\mathrm{CuZnWO}_{4}-\mathrm{rGO}$ shows lower intensity than $\mathrm{CuZnWO}_{4}[29,30]$. The results demonstrate the recombination capability rate of electrons as well as holes is inhibited considerably in CuZnWO 4 -rGO composite

\subsection{Scanning Electron Microscope (SEM)}


The SEM images of $\mathrm{CuZnWO}_{4}$ and $\mathrm{CuZnWO}_{4}-\mathrm{rGO}$ are revealed in Fig. 5. CuZnWO 4 shows a composed structure of plates and rod-like/crystal structure (Fig. 5(a and b))[31]. $\mathrm{CuZnWO}_{4}-\mathrm{rGO}$ revealed the plate as well as improved rod-like structure(Fig. 5(c and d).The closely crammed surface structure of the $\mathrm{CuZnWO}_{4}-\mathrm{rGO}$ composite particles is beneficial for effectual charge transporter separation[32,33].

\subsection{Photocatalytic activity}

The photocatalytic efficiency of the synthesized samplesis examined by degradation of organic pollutant (methylene blue (MB)) under visible light irradiation. Fig. 6 demonstrate the $\mathrm{MB}$ dye degradation using pure $\mathrm{CuZnWO}_{4}$ and $\mathrm{CuZnWO}_{4} / \mathrm{rGO}$ composite. The $\mathrm{MB}$ aqueous solution displayed the absorbance band at $\lambda=661 \mathrm{~nm}$ is shown in Fig. $6(\mathrm{a}, \mathrm{b})$. The initial absorbance peak intensity is gradually decreased with the increment of irradiation time from 0 $\min -80$ min owing to the disintegration of $\mathrm{MB}$ dye on the catalyst surface. The pure $\mathrm{CuZnWO}_{4}$ shows $51 \%$ degradation of MB dye for 80 min under visible light, but the composite shows 73 $\%$ of degradation owing to the existence of rGO. which improve the catalytic performance of $\mathrm{CuZnWO}_{4}$. The efficiency of the synthesized materials is compared with previous reports given in Table-1.

$\mathrm{MB}$ degrade and form $\mathrm{H}_{2} \mathrm{O}, \mathrm{CO}_{2}$ and some other inorganic contaminants after photocatalytic degradation. The probable degradation mechanism of $\mathrm{MB}$ dye by $\mathrm{CuZnWO}_{4}$ and its composite is clearly clarified in following equations. Initially the $\mathrm{CuZnWO}_{4}$ is irradiated by visible light, it captivates the energy approximately equal/higher than its band-gap to enable the development of electron-hole pairs. The electron from the valance band (VB) moved to the vacant conduction band (CB), results show holes formation in the VB and electrons in $\mathrm{CB}$. The oxygen molecules are reduced by highly exited electrons and form a super oxide radical $\left(* \mathrm{O}_{2}^{-}\right)$ and also, water molecules oxidized by fast-responsive electron holes to form hydroxy radicals $(* \mathrm{OH}) . * \mathrm{O}_{2}^{-}$and $* \mathrm{OH}$ radicals are fully responsible for the photocatalytic degradation of organic pollutants into $\mathrm{CO}_{2}, \mathrm{H}_{2} \mathrm{O}$ and some other inorganic contaminants as a product $[34,35]$.

$$
\begin{gathered}
\mathrm{CuZnWO}_{4}+h v \text { (visible light) } \rightarrow \mathrm{CuZnWO}_{4}\left(\mathrm{~h}^{+}+\mathrm{e}^{-}\right) \\
\mathrm{rGO}+h v \rightarrow \mathrm{e}^{-}-(3) \\
e^{-}+\mathrm{O}_{2} \rightarrow \mathrm{O}_{2}^{--}-\text {(4) }
\end{gathered}
$$




$$
\begin{gathered}
\mathrm{O}_{2}^{--}+\mathrm{H}_{2} \mathrm{O} \rightarrow \mathrm{OH}-(5) \\
h^{+}+\mathrm{H}_{2} \mathrm{O} \rightarrow \mathrm{OH}-(6) \\
\mathrm{O}_{2}^{-} / \mathrm{OH}^{-} / h^{-}+\mathrm{MB} \rightarrow \text { degradation products }\left(\mathrm{CO}_{2}+\mathrm{H}_{2} \mathrm{O}\right)-(7)
\end{gathered}
$$

\section{Photocatalytic reaction pathway of $\mathrm{MB}$}

Fig. 7 shows MB's chemical structure and the pathway of the photocatalytic reaction. In photocatalytic degradation, n-dealkylation of dyes holding auxo-chromic alkylamine groups play a key role. When part of a methyl groups degrades, the color of MB solutions has become frailer (color less) and hypochromic change takes place. Therefore, Methylene blue demethylation appears at first as defined in the pathway, and finally $\mathrm{MB}$ depredated to $\mathrm{CO}_{2}, \mathrm{H}_{2} \mathrm{O}$ and some other inorganic components[36,37].

Fig. 8(a) shows the degradation efficiency of the synthesized samples. To understand the quantitative kinetics of the MB dye degradation reaction, the degradation data is fit by first order kinetics model, using eq(8).

$$
-\ln \left(\frac{C_{t}}{C_{0}}\right)=K t-(8)
$$

Where $\mathrm{k}$ is $\min ^{-1}$ rate constant of the reaction and $\mathrm{t}$ is min are the seeming first-order rate constants and treatment time, $\mathrm{C}_{0}$ - initial concentration of dye and $\mathrm{C}_{\mathrm{t}}$ is remaining concentration of dye at each period. model fitting-plots and consistent $\mathrm{k}$ standards are revealed in Fig. 8(a,b). we calculate the seeming reaction-rate constant from slope of the plot of $\ln \left(\mathrm{C}_{0} / \mathrm{C}\right) \mathrm{Vs}$ irradiation time. From these plots, we attain the synthesized samples rate constant, the data are shown in Fig. 8(c), the result confirmed that $\mathrm{CuZnWO}_{4}-\mathrm{rGO}$ have higher catalytic degradation efficiency than $\mathrm{CuZnWO}_{4}$. The attained seeming rate constant $(\mathrm{k})$ values are 0.0151 and 0.0083 for $\mathrm{CuZnWO}_{4}-\mathrm{rGO}$ and $\mathrm{CuZnWO}_{4}$ respectively.

\subsection{Electrochemical studies}

The electrochemical properties of $\mathrm{CuZnWO}_{4}$ and $\mathrm{CuZnWO}_{4} / \mathrm{rGO}$ composite are examined by cyclic voltametric (CV) technique. In a three-electrode cell system, $\mathrm{Ag} / \mathrm{AgCl}$ is used as a reference electrode, platinum wire as a counter electrode and the synthesized samples as a working electrode in $3 \mathrm{M} \mathrm{KOH}$ aqueous electrolyte solution. Fig. 9(a) and (b) shows the CV 
curves of $\mathrm{CuZnWO}_{4}$ and $\mathrm{CuZnWO}_{4} / \mathrm{rGO}$ composite electrodes at various scan rates in between the potential range from 0 to $0.6 \mathrm{~V}$. All $\mathrm{CV}$ curves display a pair of strong redox-peaks, revealing the pseudo-capacitive features of the synthesized electrode thus the strong redox peaks are mostly governed by reversible Faradic redox process of $\mathrm{M}^{2+} / \mathrm{M}^{3+}$ [38]. According to the $\mathrm{CV}$ curve, current response of electrode material will increase with the increases of scan rates. The perfect quasi-rectangular $\mathrm{CV}$ shape of the electrodes remain constant at high scan rate, it proposes perfect capacitive behaviour. The potential of oxidation and reduction peaksare moved towards more positive and move negative respectively, which is mostly associated with the internal resistance of the electrode. The $\mathrm{CV}$ curves of $\mathrm{CuZnWO}_{4} / \mathrm{rGO}$ composite shows higher current density and specific surface area than $\mathrm{CuZnWO}_{4}$ due to the synergic effects in between rGO and $\mathrm{CuZnWO}_{4}$, which enhance the electro chemical performance and specific capacitance[39].

Galvanic charge discharge (GCD) measurements of the synthesized samples are conducted at various current density ranges between 4 and $20 \mathrm{Ag}^{-1}$ (Fig. 9(c) and (d)). CuZnWO $4 / \mathrm{rGO}$ composite offer higher $\mathrm{Cs}\left(480 \mathrm{Fg}^{-1}\right)$ than $\mathrm{CuZnWO}_{4}$ electrode $\left(15 \mathrm{Fg}^{-1}\right)$ at the same currentdensity of $4 \mathrm{Ag}^{-1}$. The $\mathrm{CuZnWO}_{4} / \mathrm{rGOcomposite} \mathrm{shows} \mathrm{superior} \mathrm{electrochemical} \mathrm{performance}$ than pristine $\mathrm{CuZnWO}_{4}$ electrode due to the synergetic effect of electroactive and porous rGO sheets[40], which boost the number of oxidation states, accessible interaction shells and enables the kinetics of ions and electrons transference from the electrolyte. The specific capacitance (Cs) or charge/discharge time decreases with increasing energy density, due to the fact of that the electrolyte-ions are unable to entirely access the internal surface area of the active-materials for charge-storing owing to the decreased diffusion time at high energy density. The Cs is calculated from GCD using the following equation[41-43]

$$
C_{s}=I \times \Delta_{t} /_{\Delta_{v}} \times m-(8)
$$

Where, Cs - specific capacitance, I - response current, $\Delta \mathrm{t}$ - discharging time, V Potential window, and $\mathrm{m}$ - mass (g) of active material. The calculated specific capacitance $(\mathrm{Cs})$ of $480,465,340,295,276,252,248,243,240 \mathrm{~F} \mathrm{~g}^{-1}$ at current density of 4, 6, 8, 10, 12, 14, 16, $18,20 \mathrm{~A} \mathrm{~g}^{-1}$,respectively.

The comparison of GCD curve (Fig.10(a)) is revealed that the $\mathrm{CuZnWO}_{4} / \mathrm{rGO}$ composite offer higher charging and discharging time than pristine $\mathrm{CuZnWO}_{4}$, due to the high surface area 
of rGO based composite [44]. Fig.10(b)shows the specific capacitance comparison of the synthesized electrode materials. It clearly shows that the composite has higher specific capacitance than $\mathrm{CuZnWO}_{4}$.Amazingly, the increasing cyclability of $\mathrm{CuZnWO} / \mathrm{rGO}$ composite electrode is shown in Fig.10(c). The CuZnWO $/$ rGO offercyclic retention of $127 \%$ at $20 \mathrm{~A} \mathrm{~g}^{-1}$ due to the continuous charging/discharging process raises the wettability of $\mathrm{CuZnWO}_{4} / \mathrm{rGO}$, where enhanced the diffusion of electrolyte ions to the electrode material. Thecontinues activation of $\mathrm{CuZnWO}_{4} / \mathrm{rGO}$ composite during charging/discharging process that increase the interaction between electrode and electrolyte ions, resulting to increasespecific capacitance (Cs increases with number of charging/discharging cycles)[45-47]. Electrochemical impedance spectra (EIS) of the synthesized electrode materials isillustrated in Fig.10(d). The internal and external resistance of the synthesized electrode materials and electrode/electrolyte are estimated via open circuit potentials (OCP) from 0.1 to $105 \mathrm{~Hz}$ respectively. In Fig. 10(d) shows the Nyquist plot and circuit diagram of $\mathrm{CuZnWO}_{4}$ and $\mathrm{CuZnWO}_{4} / \mathrm{rGO}$ composite. Pristine $\mathrm{CuZnWO}_{4}$ shows more resistance than the $\mathrm{CuZnWO}_{4} / \mathrm{rGO}$ composite from this EIS spectra we conclude that the composite offers higher electrochemical performance and specific capacitance due to the lower internal resistance.

\section{Conclusion}

In the present work, we synthesized a nano-structured bimetallic tungstate $\mathrm{CuZnWO}_{4}$ and its composite with rGO via hydrothermal method. The synthesized materials are used as a catalyst for photocatalytic activity and electrode for SCs. $\mathrm{CuZnWO}_{4} / \mathrm{rGO}$ shows better photocatalytic activity and electrochemical performance than pristine $\mathrm{CuZnWO}_{4}$ due to efficient interaction of rGO, the high surface area of rGO is captured more electrons for efficient degradation of organic pollutants with degradation efficiency of $73 \%$ (CuZnWO $4 / \mathrm{rGO})$. The electrochemical performance of the synthesized composite electrode ( $\left.\mathrm{CuZnWO}_{4} / \mathrm{rGO}\right)$ shows the Cs $480 \mathrm{Fg}^{-1}$ at $4 \mathrm{Ag}^{-1}$ in aqueous $6 \mathrm{M} \mathrm{KOH}$ electrolyte respectively, the electrode reveals enhanced cyclability of $127 \%$ at $20 \mathrm{Ag}^{-1}$ after 5000 cycles due to the increasing of interaction between electrode and electrolyte. The synergetic effect of $\mathrm{CuZnWO}_{4}$ and $\mathrm{rGO}$ lead to high storage capacity and outstanding cyclability. The above results confirmed that the synthesized material is a potential candidate for photocatalytic and supercapacitor application. 


\section{Acknowledgement}

Dr.Navaneethan Duraisamy acknowledges the DST, New Delhi, India, for the DST Inspire Faculty award (DST/INSPIRE/04/ 2018/001444).

\section{Reference}

1. J. Yesuraj and S. A. Suthanthiraraj, J. Mol. Struct. 1181, 131 (2019).

2. K. T. G. Carvalho, O. F. Lopes, D. C. Ferreira, and C. Ribeiro, J. Alloys Compd. 797, 1299 (2019).

3. S. M. Alshehri, J. Ahmed, T. Ahamad, N. Alhokbany, P. Arunachalam, A. M. Al-Mayouf, and T. Ahmad, J. Sol-Gel Sci. Technol. 87, 137 (2018).

4. S. Chen, G. Yang, Y. Jia, and H. Zheng, ChemElectroChem 3, 1490 (2016).

5. K. Adib, M. Rahimi-Nasrabadi, Z. Rezvani, S. M. Pourmortazavi, F. Ahmadi, H. R. Naderi, and M. R. Ganjali, J. Mater. Sci. Mater. Electron. 27, 4541 (2016).

6. V. Faka, S. Tsoumachidou, M. Moschogiannaki, G. Kiriakidis, I. Poulios, and V. Binas, J. Photochem. Photobiol. A Chem. 406, 113002 (2021).

7. U. M. García-Pérez, A. Martínez-De La Cruz, and J. Peral, Electrochim. Acta 81, 227 (2012).

8. J. Ahmed, T. Ahamad, N. Alhokbany, B. M. Almaswari, T. Ahmad, A. Hussain, E. S. S. AlFarraj, and S. M. Alshehri, ChemElectroChem 5, 3938 (2018).

9. S. Kundu, L. Ma, Y. Chen, and H. Liang, J. Photochem. Photobiol. A Chem. 346, 249 (2017).

10. S. M. Alshehri, J. Ahmed, A. M. Alzahrani, and T. Ahamad, New J. Chem. 41, 8178 (2017).

11. A. A. G. Santiago, R. L. Tranquilin, M. S. Li, E. Longo, F. V. Motta, and M. R. D. Bomio, Mater. Chem. Phys. 258, 123991 (2021).

12. H. He, Z. Luo, Z. Y. Tang, and C. Yu, Appl. Surf. Sci. 490, 460 (2019).

13. M. Liu, L. Gan, W. Xiong, F. Zhao, X. Fan, D. Zhu, Z. Xu, Z. Hao, and L. Chen, Energy and Fuels 27, 1168 (2013).

14. M. N. Rantho, M. J. Madito, and N. Manyala, J. Alloys Compd. 819, 152993 (2020).

15. R. D. Kumar, Y. Andou, and S. Karuppuchamy, J. Alloys Compd. 654, 349 (2016).

16. H. Naderi, H. Sobati, A. Sobhani-Nasab, M. Rahimi-Nasrabadi, M. Eghbali-Arani, M. R. Ganjali, and H. Ehrlich, ChemistrySelect 4, 2862 (2019).

17. R. Dhilip Kumar and S. Karuppuchamy, J. Alloys Compd. 674, 384 (2016).

18. J. Jo, S. Lee, J. Gim, J. Song, S. Kim, V. Mathew, M. H. Alfaruqi, S. Kim, J. Lim, and J. 
Kim, R. Soc. Open Sci. 6, (2019).

19. M. Mosleh and K. Taherinejat, J. Mater. Sci. Mater. Electron. 27, 10510 (2016).

20. C. Wei, Y. Huang, X. Zhang, X. Chen, and J. Yan, Electrochim. Acta 220, 156 (2016).

21. L. Xu, X. Wang, M. L. Xu, B. Liu, X. F. Wang, S. H. Wang, and T. Sun, Ultrason. Sonochem. 61, 104815 (2020).

22. K. Qureshi, M. Z. Ahmad, I. A. Bhatti, M. Zahid, J. Nisar, and M. Iqbal, J. Mol. Liq. 285, 778 (2019).

23. K. S. Samantaray, S. Sahoo, and C. S. Rout, Am. J. Eng. Appl. Sci. 9, 584 (2016).

24. S. Muthamizh, R. Suresh, K. Giribabu, R. Manigandan, S. P. Kumar, S. Munusamy, L. Vijayalakshmi, A. Stephen, and V. Narayanan, AIP Conf. Proc. 1591, 508 (2014).

25. B. Kavitha and R. Karthiga, 11, 57 (2020).

26. W. Zhang, J. Yin, F. Min, L. Jia, D. Zhang, Q. Zhang, and J. Xie, J. Alloys Compd. 690, 221 (2017).

27. Z. Amouzegar, R. Naghizadeh, H. R. Rezaie, M. Ghahari, and M. Aminzare, Ceram. Int. 41, 8352 (2015).

28. N. Hu, Z. Yang, Y. Wang, L. Zhang, Y. Wang, X. Huang, H. Wei, L. Wei, and Y. Zhang, Nanotechnology 25, (2014).

29. Y. Tang, N. Rong, F. Liu, M. Chu, H. Dong, Y. Zhang, and P. Xiao, Appl. Surf. Sci. 361, 133 (2016).

30. S. Roddaeng, P. Promvonge, and R. Anuwattana, MATEC Web Conf. 192, 8 (2018).

31. P. V. Adhyapak, A. D. Bang, P. More, and N. R. Munirathnam, RSC Adv. 8, 34035 (2018).

32. S. Zhong, C. Li, M. Shen, C. Lv, and S. Zhang, J. Mater. Res. Technol. 8, 1849 (2019).

33. A. K. Adepu, S. Goskula, S. Chirra, S. Siliveri, S. R. Gujjula, and V. Narayanan, RSC Adv. 9, 24368 (2019).

34. M. Thiruppathi, K. Leeladevi, C. Ramalingan, K. C. Chen, and E. R. Nagarajan, Mater. Sci. Semicond. Process. 106, 104766 (2020).

35. C. P. Goyal, D. Goyal, V. Ganesh, N. S. Ramgir, M. Navaneethan, Y. Hayakawa, C. Muthamizhchelvan, H. Ikeda, and S. Ponnusamy, Phys. Solid State 62, 1796 (2020).

36. X. Q. Wang, S. F. Han, Q. W. Zhang, N. Zhang, and D. D. Zhao, MATEC Web Conf. 238, (2018).

37. R. S. Dariani, A. Esmaeili, A. Mortezaali, and S. Dehghanpour, Optik (Stuttg). 127, 7143 
(2016).

38. R. Dhilip Kumar, Y. Andou, M. Sathish, and S. Karuppuchamy, J. Mater. Sci. Mater. Electron. 27, 2926 (2016).

39. J. Tang, J. Shen, N. Li, and M. Ye, Facile Synthesis of Layered MnWO4/reduced Graphene Oxide for Supercapacitor Application (2016).

40. M. Mitra, S. T. Ahamed, A. Ghosh, A. Mondal, K. Kargupta, S. Ganguly, and D. Banerjee, ACS Omega 4, 1623 (2019).

41. X. Xing, Y. Gui, G. Zhang, and C. Song, Electrochim. Acta 157, 15 (2015).

42. J. Chu, X. Li, Q. Li, J. Ma, B. Wu, X. Wang, R. Zhang, M. Gong, and S. Xiong, High Perform. Polym. 32, 258 (2020).

43. K. Seevakan, A. Manikandan, P. Devendran, Y. Slimani, A. Baykal, and T. Alagesan, Ceram. Int. 44, 20075 (2018).

44. A. Iakunkov, V. Skrypnychuk, A. Nordenström, E. A. Shilayeva, M. Korobov, M. Prodana, M. Enachescu, S. H. Larsson, and A. Vtalyzin, Phys. Chem. Chem. Phys. 21, 17901 (2019).

45. A. E. Elkholy, A. S. Dhmees, F. E. T. Heakal, and M. A. Deyab, New J. Chem. 43, 1987 (2019).

46. M. Ramadan, A. M. Abdellah, S. G. Mohamed, and N. K. Allam, Sci. Rep. 8, 1 (2018).

47. J. Zhou, J. Lian, L. Hou, J. Zhang, H. Gou, M. Xia, Y. Zhao, T. A. Strobel, L. Tao, and F. Gao, Nat. Commun. 6, (2015).

48. M. Mousavi, A. Habibi-Yangjeh, and M. Abitorabi, J. Colloid Interface Sci. 480, 218 (2016).

49. R. Salimi, A. A. Sabbagh Alvani, N. Naseri, S. F. Du, and D. Poelman, New J. Chem. 42 , 11109 (2018).

50. A. M. Raba-Páez, J. O. João, C. A. Parra-Vargas, E. C. Paris, and M. Rincón-Joya, Mater. Today Commun. (2020).

51. W. Zou, L. Zhang, L. Liu, X. Wang, J. Sun, S. Wu, Y. Deng, C. Tang, F. Gao, and L. Dong, Appl. Catal. B Environ. 181, 495 (2016).

52. H. Wang, X. Yuan, H. Wang, X. Chen, Z. Wu, L. Jiang, W. Xiong, and G. Zeng, Appl. Catal. B Environ. 193, 36 (2016).

53. M. Rahimi-Nasrabadi, S. M. Pourmortazavi, M. Aghazadeh, M. R. Ganjali, M. S. Karimi, and P. Novrouzi, J. Mater. Sci. Mater. Electron. 28, 3780 (2017).

54. S. Ameen, H. K. Seo, M. Shaheer Akhtar, and H. S. Shin, Chem. Eng. J. 210, 220 (2012). 
55. B. G. S. Raj, J. Acharya, M. K. Seo, M. S. Khil, H. Y. Kim, and B. S. Kim, Int. J. Hydrogen Energy 44, 10838 (2019).

56. R. Dhilip Kumar and S. Karuppuchamy, Ceram. Int. 40, 12397 (2014).

57. S. M. Pourmortazavi, M. Rahimi-Nasrabadi, M. S. Karimi, and S. Mirsadeghi, New J. Chem. 42, 19934 (2018).

58. D. P. Ojha, H. P. Karki, J. hee Song, and H. J. Kim, Chem. Phys. Lett. 712, 83 (2018).

59. U. Nithiyanantham, S. R. Ede, S. Anantharaj, and S. Kundu, Cryst. Growth Des. 15, 673 (2015). 


\section{Table caption}

Table - 1: Comparison of Dye degradation efficiency with previous reported literatures

Table -1 : Comparison of the electrochemical performance with previous reported literatures

\section{Figure caption}

Fig. 1. Graphical abstract

Fig. 2. XRD pattern: a) $\mathrm{CuZnWO}_{4}$ and b) $\mathrm{CuZnWO}_{4} / \mathrm{rGO}$

Fig. 3. FTIR spectra: a) $\mathrm{CuZnWO}_{4}$ and b) $\mathrm{CuZnWO}_{4} / \mathrm{rGO}$

Fig. 4. (a,b) UV-DRS absorption and transmission spectrum and (c) photoluminescence spectram and d) taucplot

Fig. 5. SEM images:a,b) $\mathrm{CuZnWO}_{4}$ and c,d) $\mathrm{CuZnWO}_{4}-\mathrm{rGO}$ low and high magnificaation respectively

Fig. 6. Photocatalytic dye degradation: a) $\mathrm{CuZnWO}_{4}$, b) $\mathrm{CuZnWO}_{4} / \mathrm{rGO}$ and c) Comparison of methylene blue degradation efficiency of $\mathrm{CuZnWO}_{4}$ andCuZnWO $4 / \mathrm{rGO}$ under visible light

Fig. 7. Ln C/Covs. irradiation time for photocatalytic degradation of MB dye

Fig. 8. Mechanism of methylene blue dye degradation

Fig. 9. Cyclic voltammograms at various scan rates from 5 to $100 \mathrm{mV} \cdot \mathrm{s}^{-1}$ a) $\mathrm{CuZnWO}_{4}$ and b) $\mathrm{CuZnWO}_{4} / \mathrm{rGO}, \mathrm{GCD}$ at various current densities from 4 to $\left.20 \mathrm{~A} \cdot \mathrm{g}^{-1} \mathrm{c}\right) \mathrm{CuZnWO}_{4}$ and d) $\mathrm{CuZnWO}_{4}$.

Fig.10. a) GCD comparison of $\mathrm{CuZnWO}_{4}$ and $\mathrm{CuZnWO}_{4} / \mathrm{rGO}$ at6 $\mathrm{Ag}^{-1}$, b)Comparison specific capacitance Vs current density c) Cyclability and culumbic efficiency ofCuZnWO $4 / \mathrm{rGO}$ d) Nyquest plots

Table 1

\begin{tabular}{|c|c|c|c|c|}
\hline Catalyst & Pollutant & $\begin{array}{l}\text { Efficiency } \\
(\%)\end{array}$ & $\begin{array}{l}\text { Time } \\
\text { (Min) }\end{array}$ & Reference \\
\hline $\mathrm{g}-\mathrm{C}_{3} \mathrm{~N}_{4} / \mathrm{Fe}_{3} \mathrm{O}_{4} / \mathrm{AgCl}$ & $\mathrm{RhB}$ & 49.5 & - & {$[48]$} \\
\hline $\mathrm{Ag}-\mathrm{CuWO} 4 / \mathrm{WO}_{3}$ & MB & 51 & 180 & [49] \\
\hline $\mathrm{CuO}$ with $\mathrm{CuWO}_{4}$ & RhB & 20 & 160 & {$[50]$} \\
\hline $\mathrm{o}-\mathrm{Cu}_{2} \mathrm{O}-\mathrm{rGO}$ & $\mathrm{MB}$ & 72 & 160 & {$[51]$} \\
\hline CNQD-utg-C ${ }_{3} \mathrm{~N}_{4}$ & $\mathrm{MO}$ & 70 & 160 & {$[52]$} \\
\hline $\mathrm{TiO}_{2}$ & $\mathrm{MB}$ & 50 & 60 & {$[53]$} \\
\hline polyaniline/graphene & RhB & 56 & 180 & {$[54]$} \\
\hline $\mathrm{CuZnWO}_{4} / \mathrm{rGO}$ & MB & & $80 \mathrm{~min}$ & This Work \\
\hline
\end{tabular}


Table-2

\begin{tabular}{|l|l|l|l|}
\hline $\begin{array}{l}\text { Electrode } \\
\text { material }\end{array}$ & Electrolyte & Specific capacitance & Reference \\
\hline $\mathrm{CoWO}_{4}$ & $2 \mathrm{M} \mathrm{H}_{2} \mathrm{SO}_{4}$ & $378 \mathrm{~F} / \mathrm{g}$ at $2 \mathrm{mV} / \mathrm{s}$ & {$[5]$} \\
\hline $\mathrm{MnWO}_{4}$ & $1 \mathrm{M} \mathrm{Na}_{2} \mathrm{SO}_{4}$ & $324 \mathrm{~F} / \mathrm{g}$ at $1 \mathrm{~mA} \mathrm{~cm}{ }^{-2}$ & {$[55]$} \\
\hline $\mathrm{CuWO}_{4}$ & $\begin{array}{l}0.1 \mathrm{M} \mathrm{KCl} \mathrm{with} \\
1 \mathrm{mM}[\mathrm{Fe}(\mathrm{CN}) 6]^{3-/ 4-}\end{array}$ & $77 \mathrm{~F} / \mathrm{g}$ & {$[56]$} \\
\hline $\mathrm{CuWO}_{4}$ & $2 \mathrm{M} \mathrm{KOH}$ & $302.40 \mathrm{mAh} / \mathrm{g}$ at $1 \mathrm{~A} / \mathrm{g}$ & {$[20]$} \\
\hline $\mathrm{Ni}^{-W_{3}}$ & $2 \mathrm{M} \mathrm{KOH}$ & $171.28 \mathrm{~F} / \mathrm{g}$ at $0.25 \mathrm{~A} / \mathrm{g}$ & {$[15]$} \\
\hline $\mathrm{CWO}_{3} \mathrm{NPs}_{\mathrm{NiWO}} \mathrm{NPs}$ & $1 \mathrm{M} \mathrm{KOH}$ & $230 \mathrm{~F} / \mathrm{g}$ at $5 \mathrm{mV} / \mathrm{s}$ & {$[8]$} \\
\hline $\mathrm{FWO} / \mathrm{gCN}$ & $3 \mathrm{M} \mathrm{H}{ }_{2} \mathrm{SO}$ & $468 \mathrm{~F} / \mathrm{g}$ at $2 \mathrm{mV} / \mathrm{s}$ & {$[57]$} \\
\hline $\mathrm{NiWO} 4$ & $2 \mathrm{M} \mathrm{KOH}$ & $357 \mathrm{~F} / \mathrm{g}$ at $5 \mathrm{mV} / \mathrm{s}$ & {$[58]$} \\
\hline $\mathrm{CuZnWO} / \mathrm{MGO}$ & $6 \mathrm{M} \mathrm{KOH}$ & $173 \mathrm{~F} / \mathrm{g}$ at $5 \mathrm{mV} / \mathrm{s}$ & {$[59]$} \\
\hline
\end{tabular}

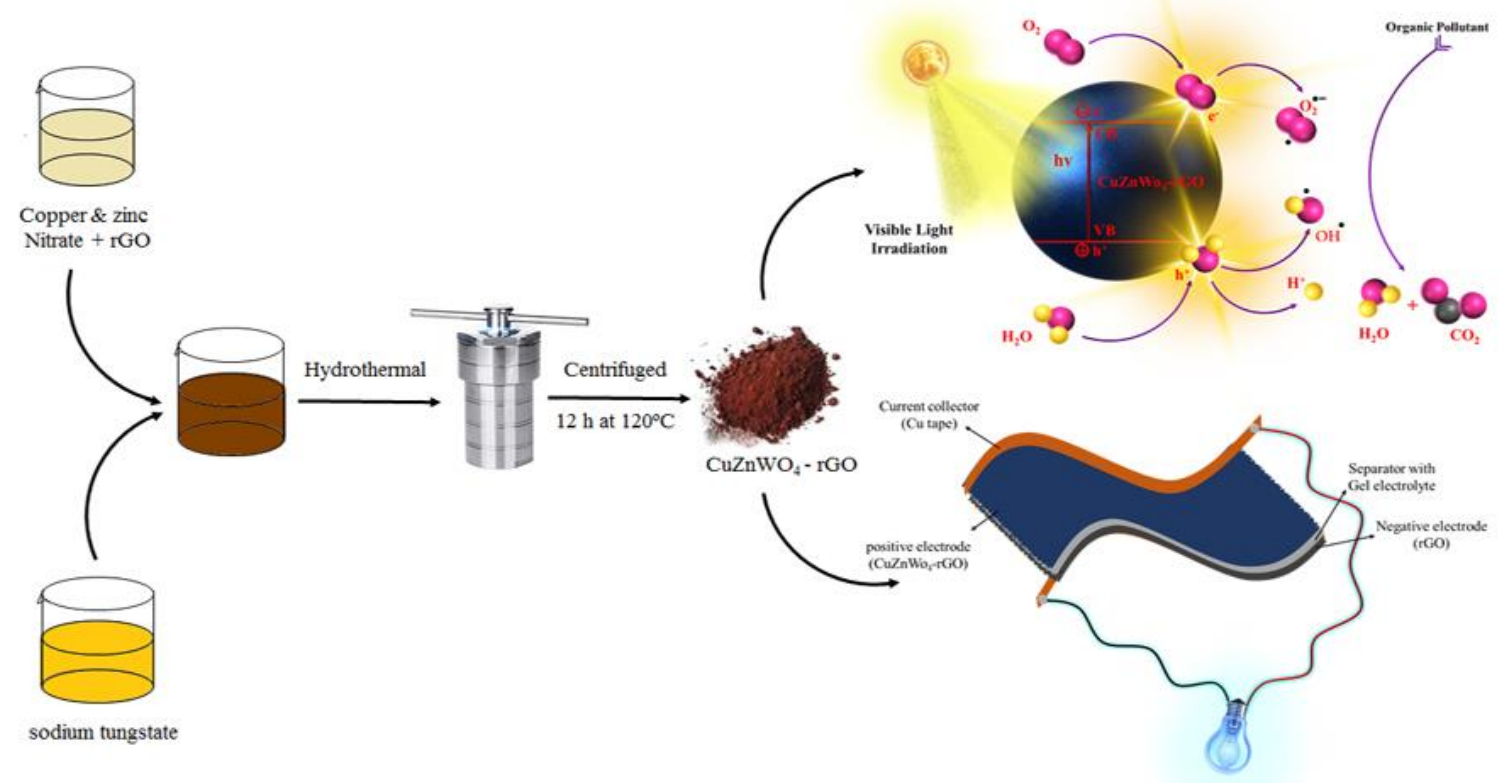

Fig. 1 


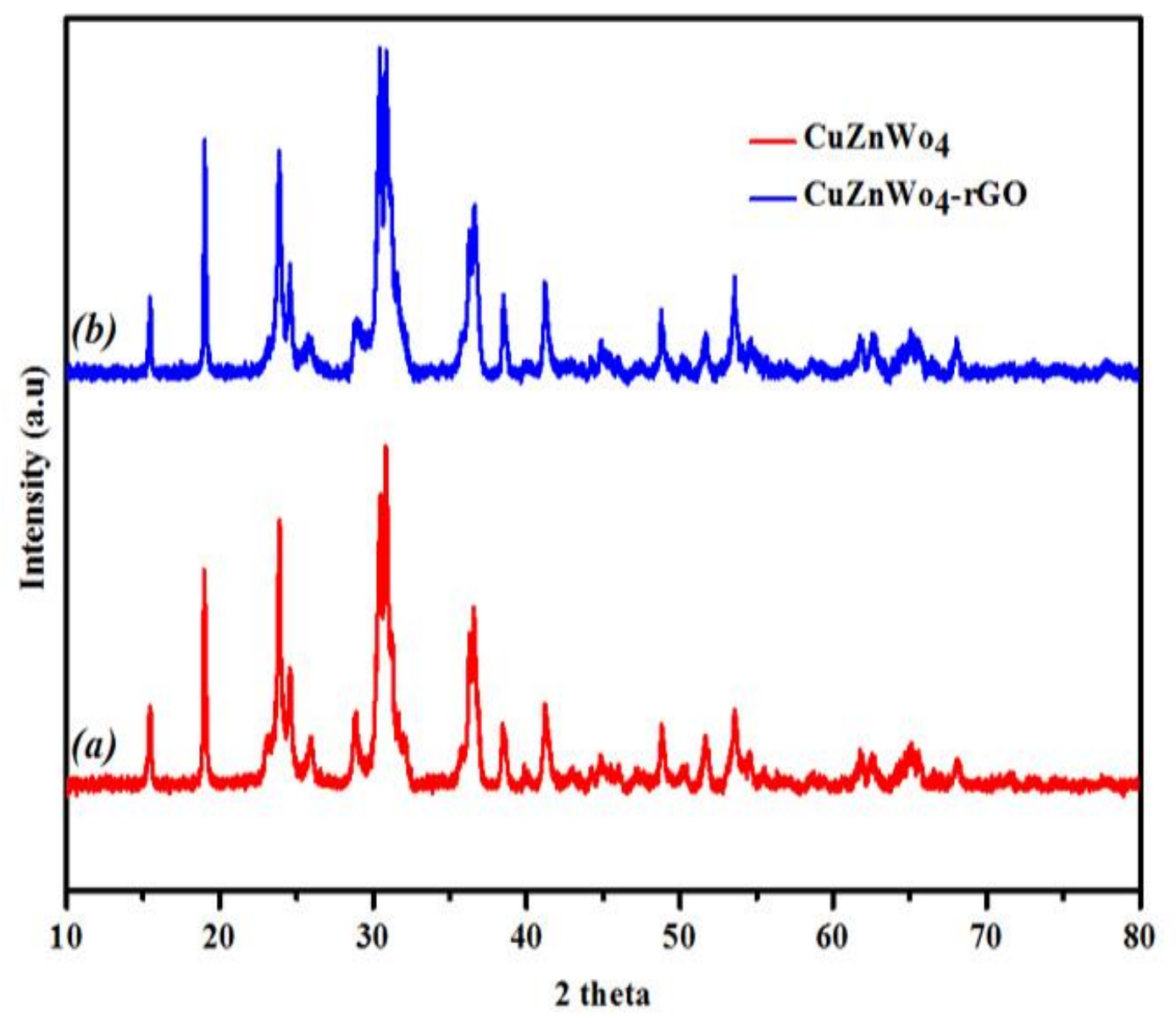

Fig. 2 


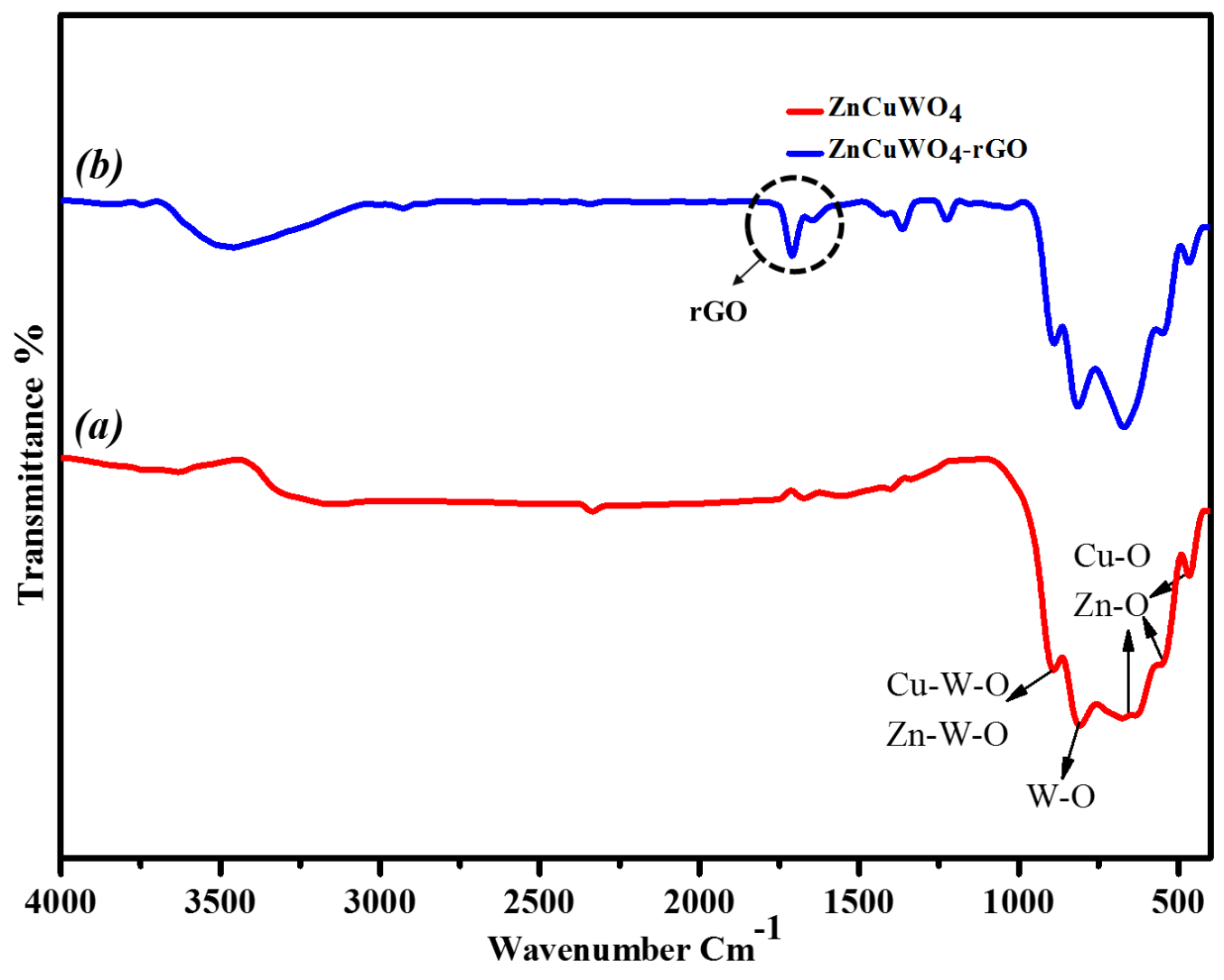

Fig. 3 

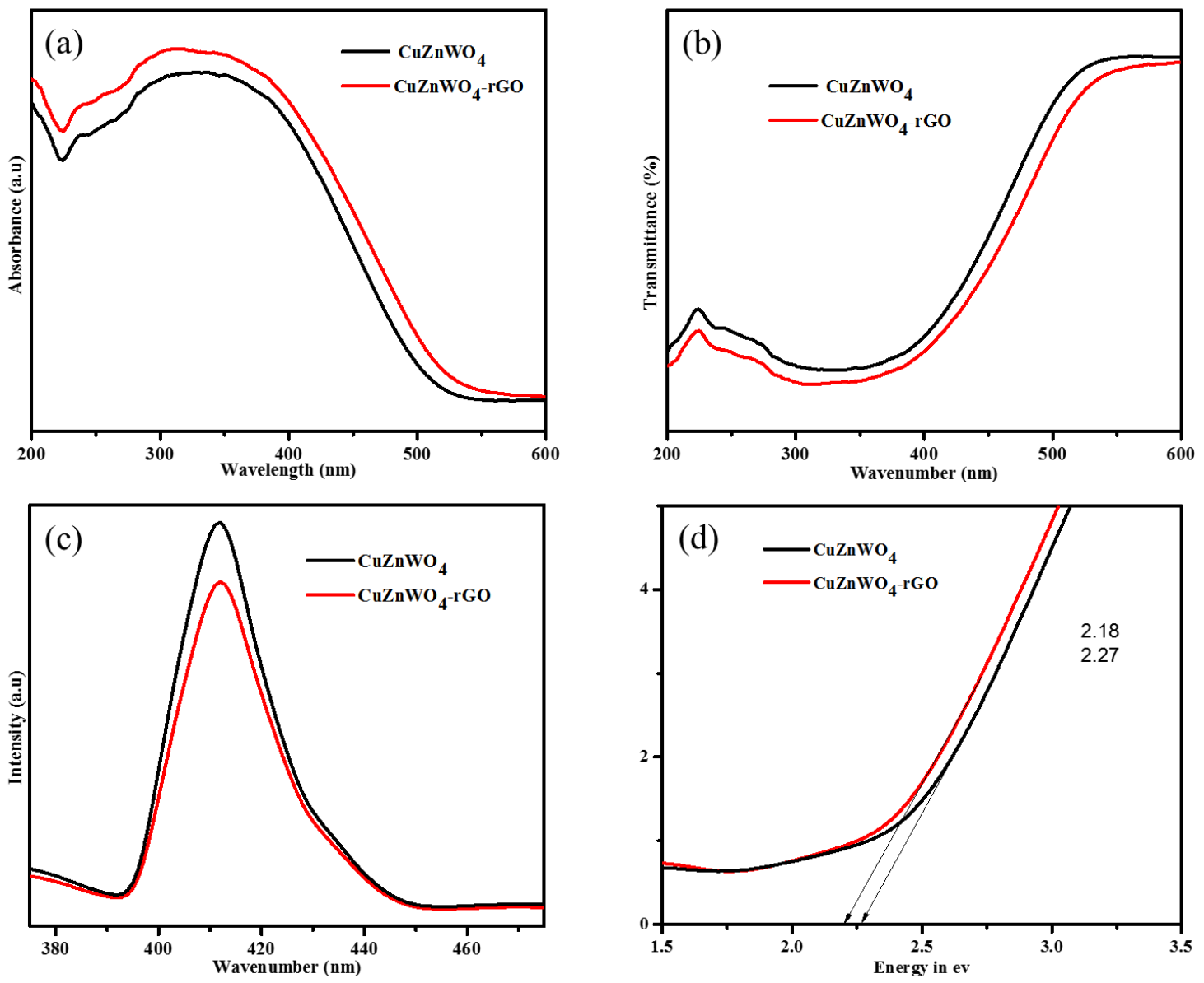

Fig. 4 


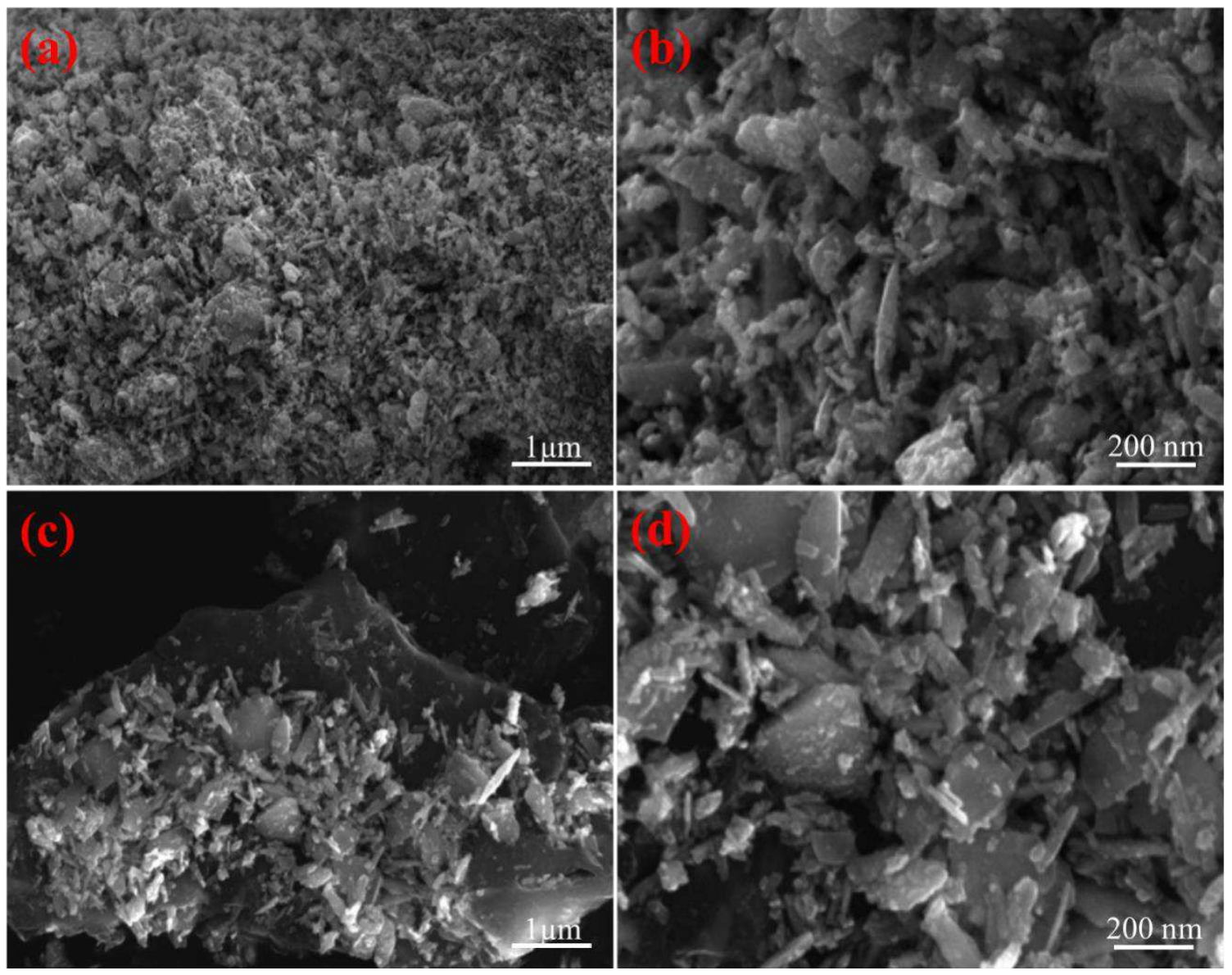

Fig. 5 

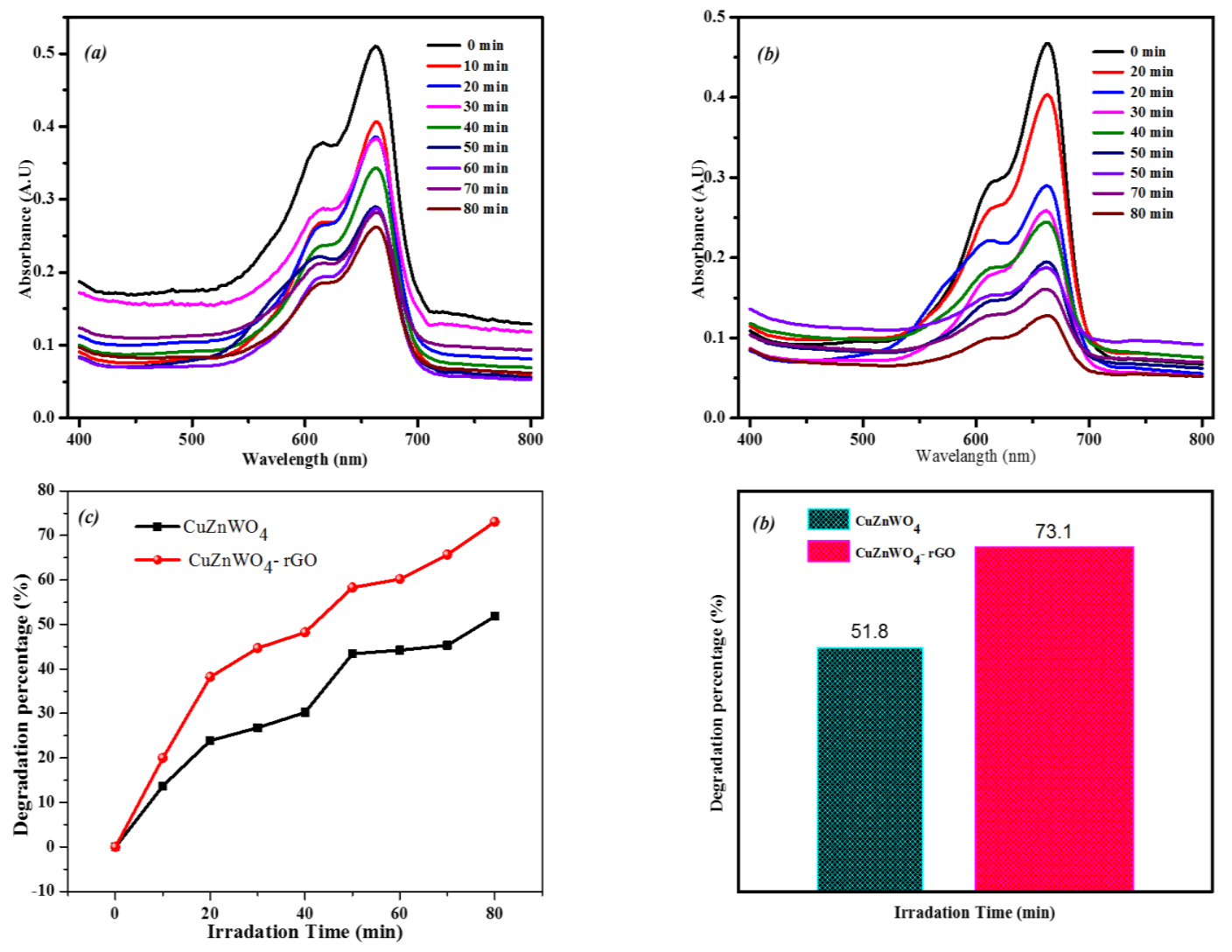

Fig. 6 

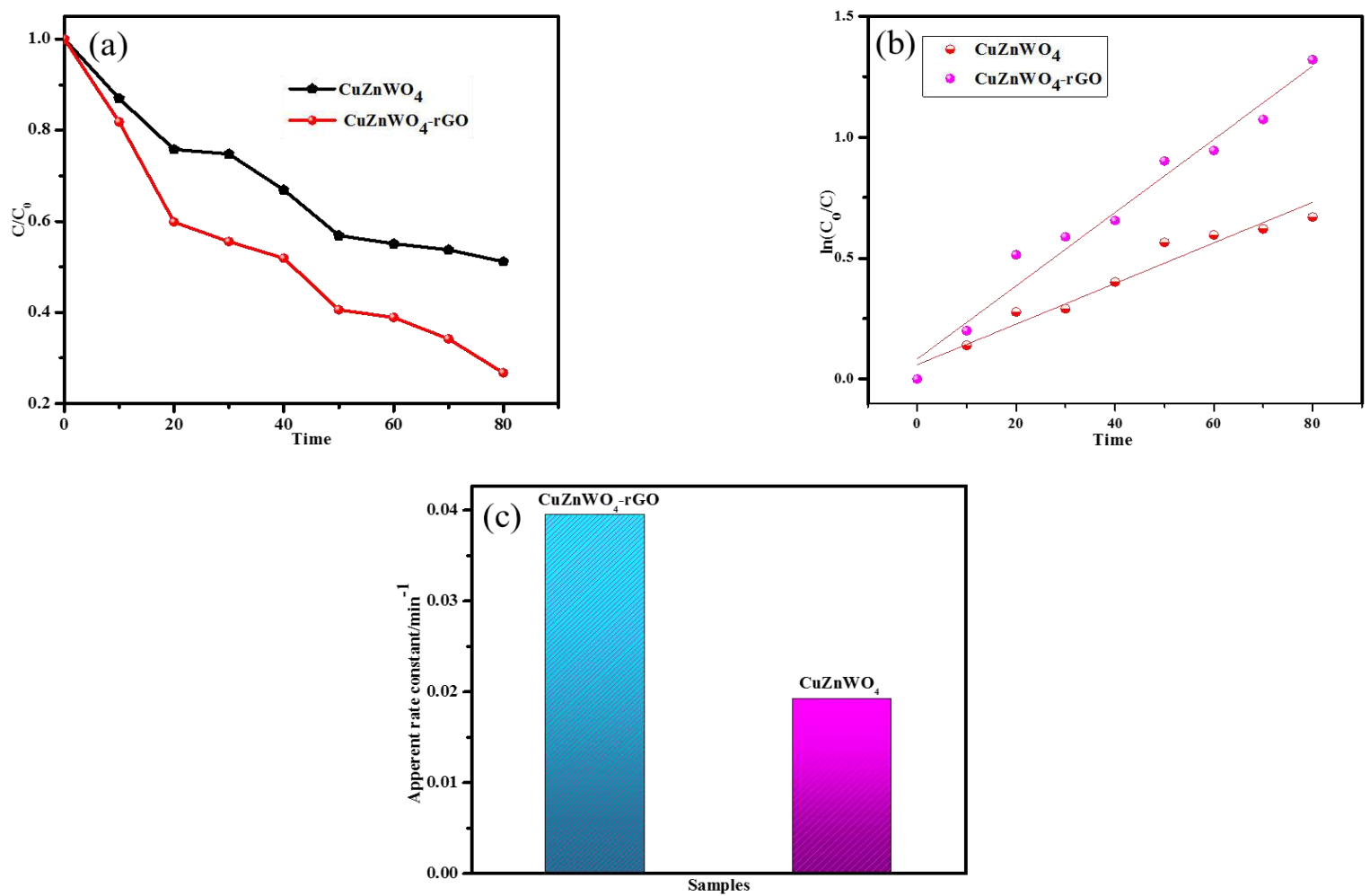

Fig. 7 


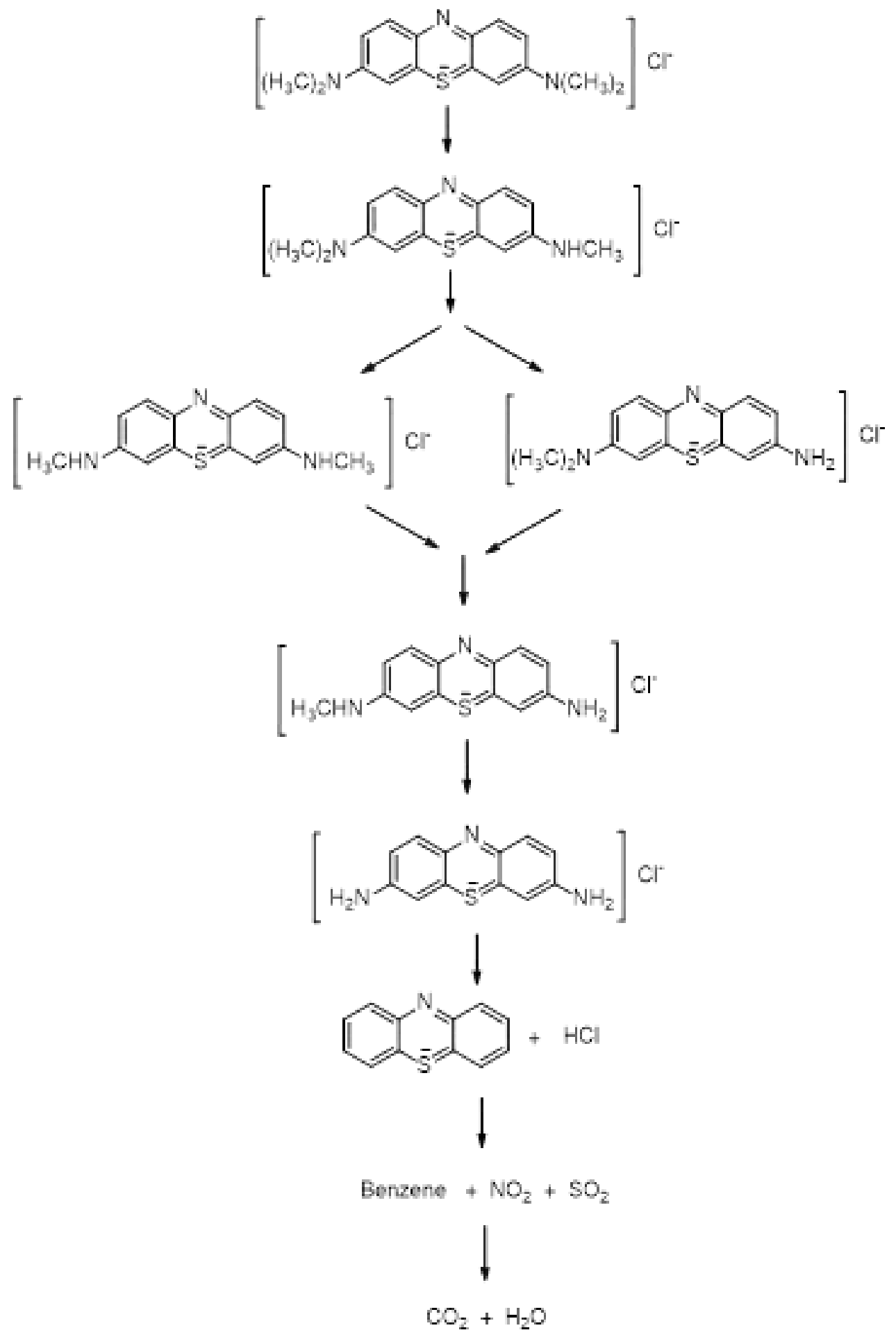

Fig. 8 

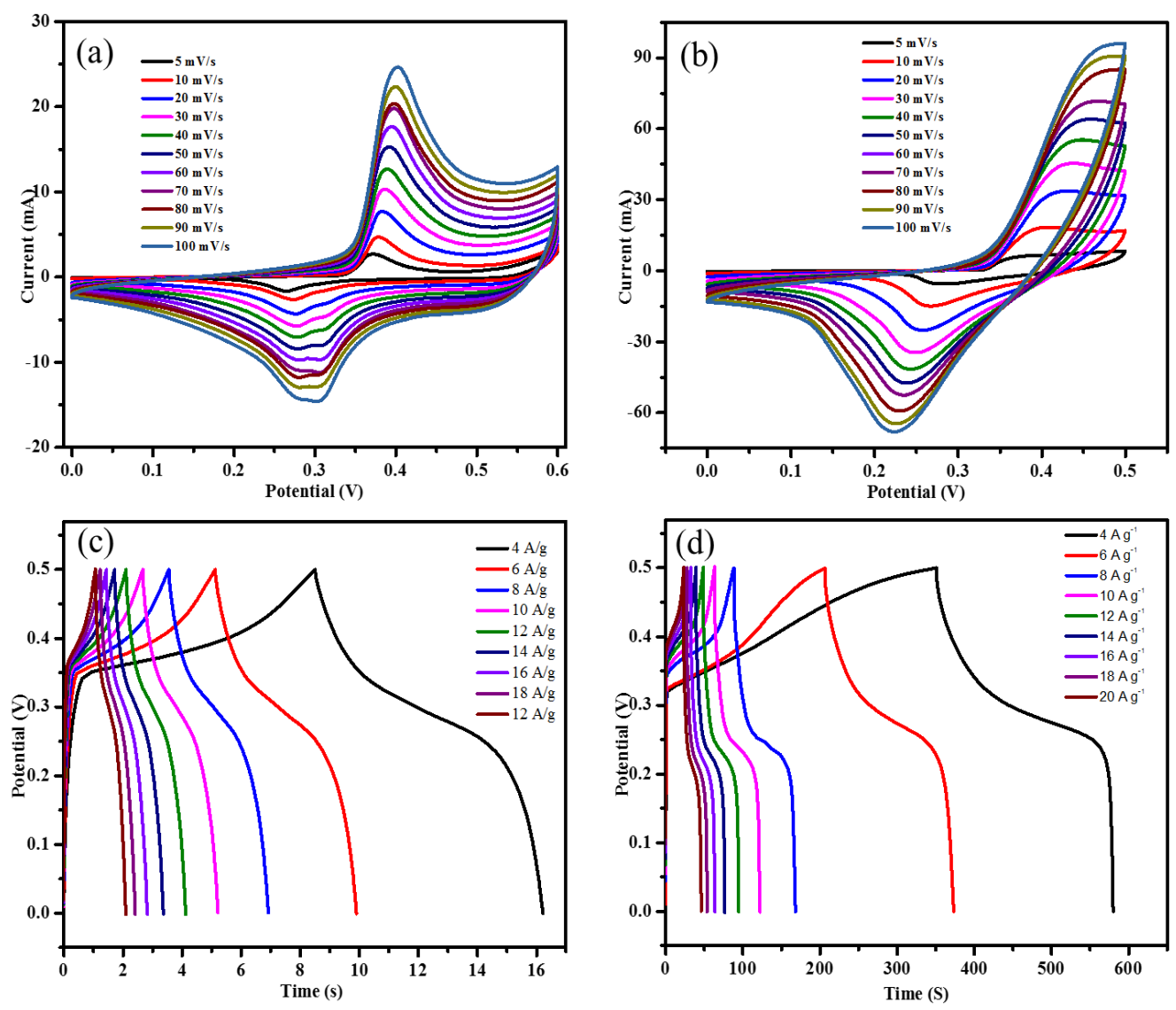

Fig. 9 

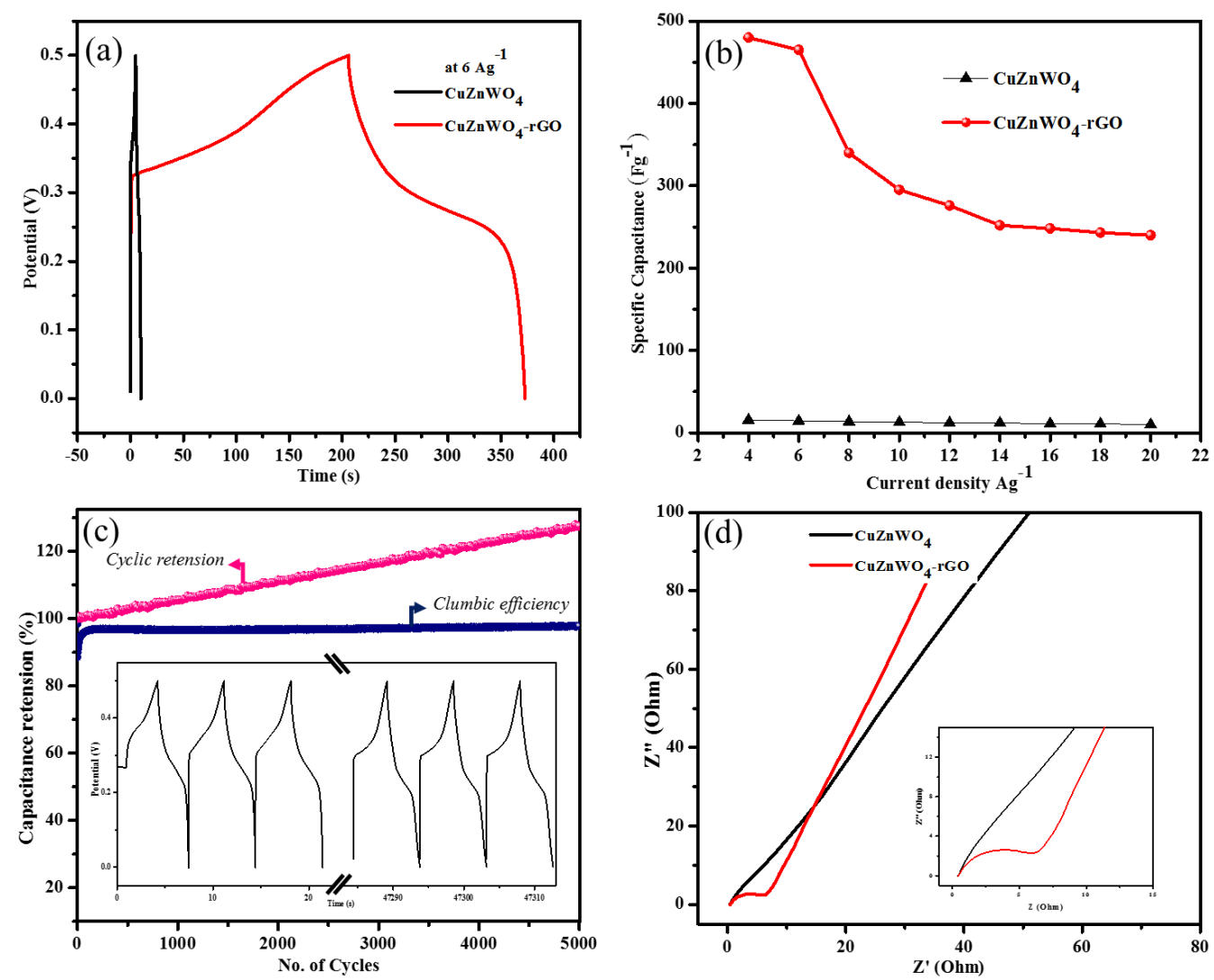

Fig. 10 
Figures

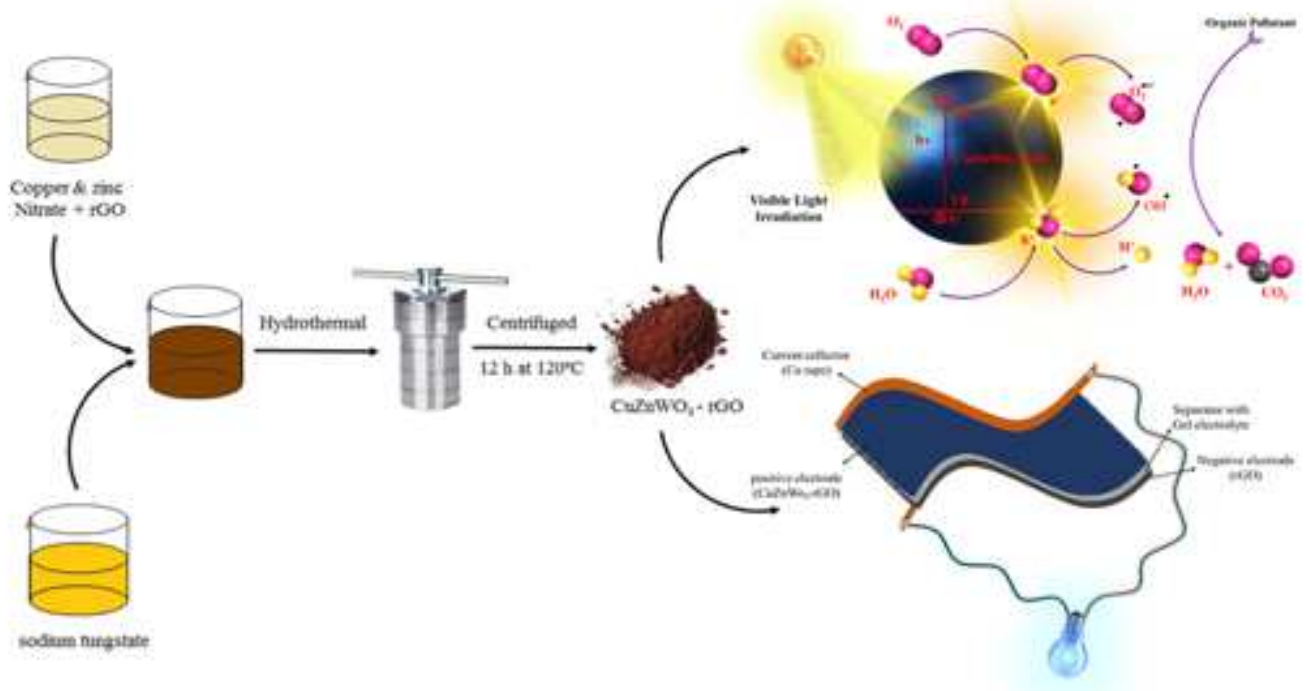

Figure 1

Graphical abstract

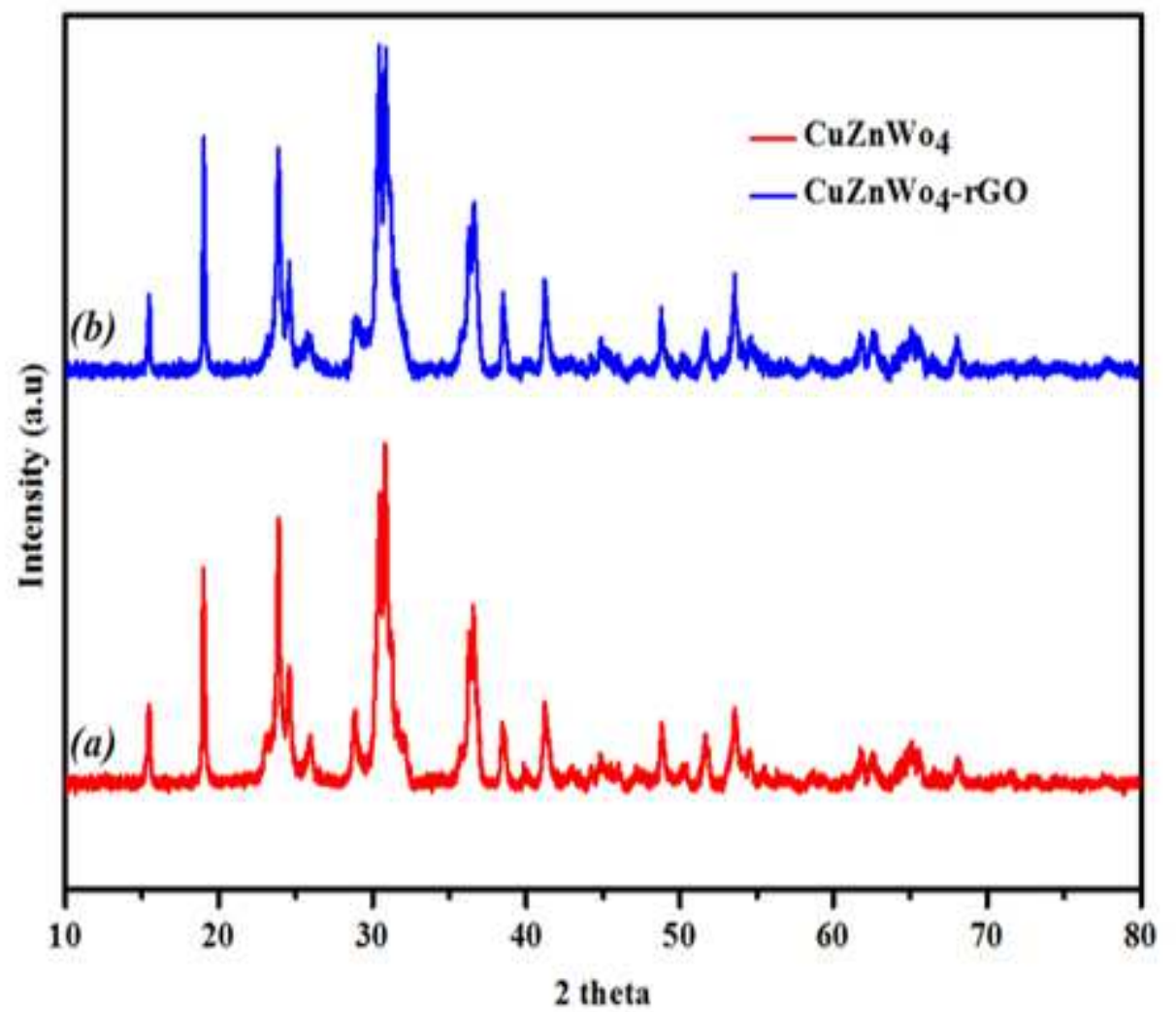

Figure 2 
XRD pattern: a) CuZnWO4 and b) CuZnWO4/rGO

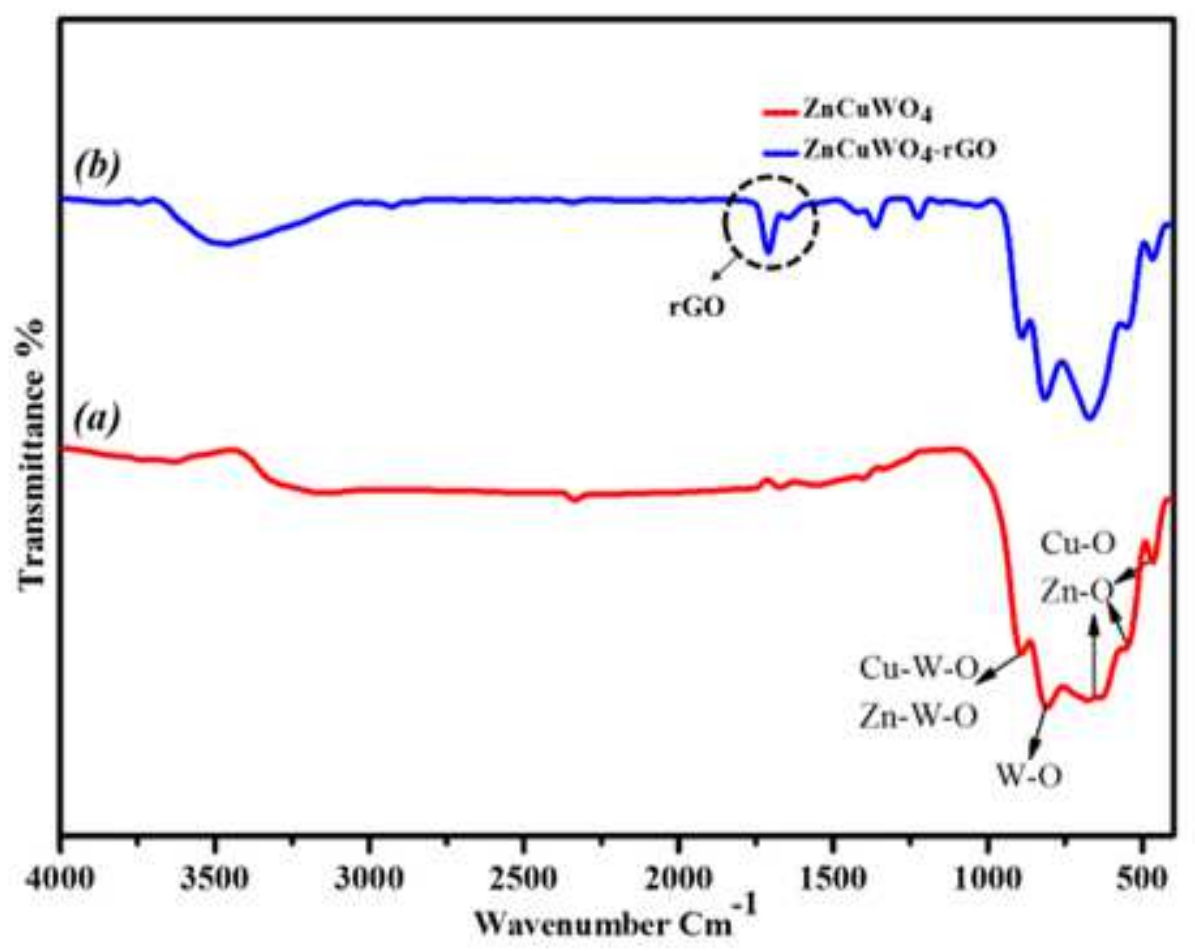

Figure 3

FTIR spectra: a) CuZnWO4 and b) CuZnWO4/rGO
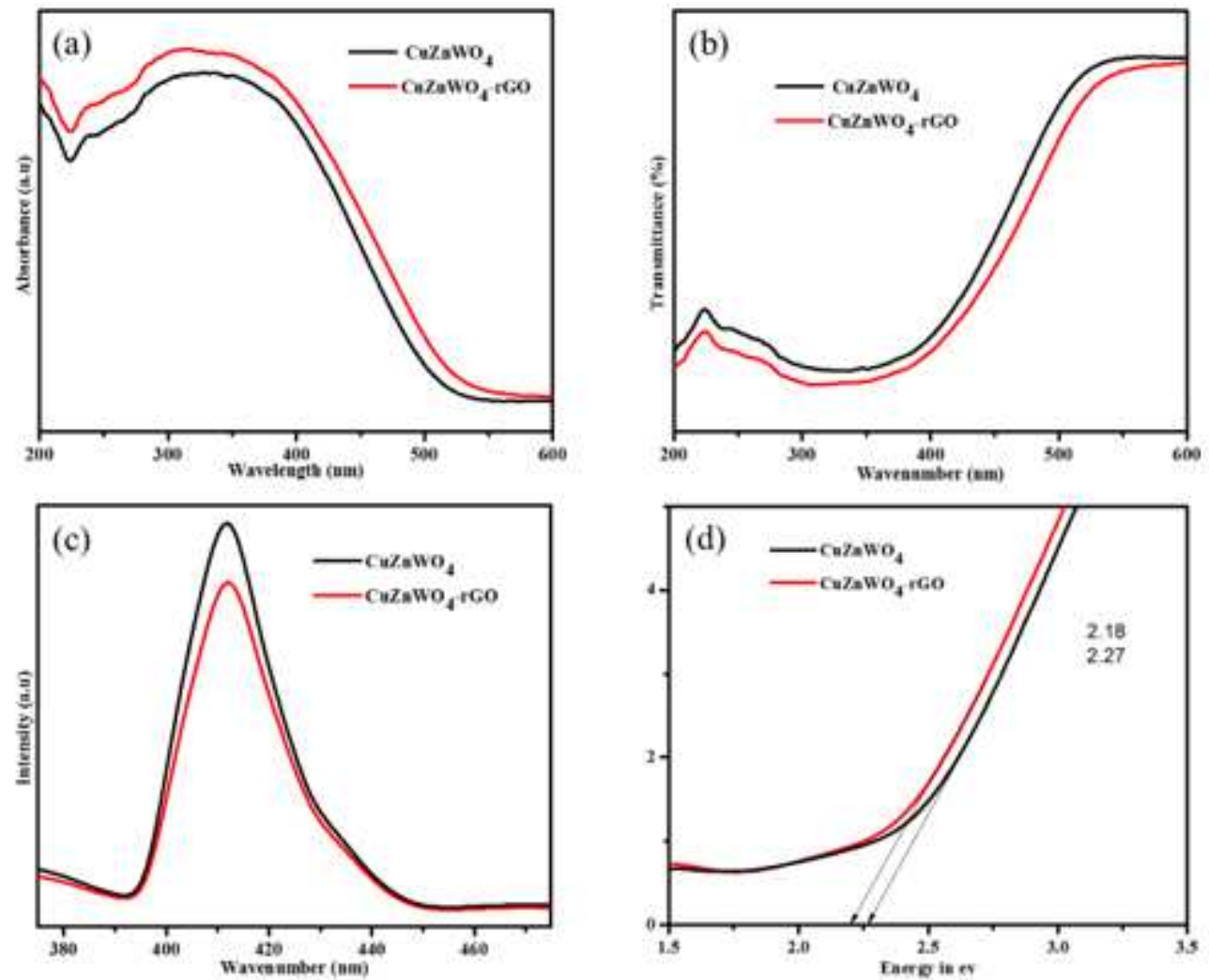
Figure 4

$(a, b)$ UV-DRS absorption and transmission spectrum and (c) photoluminescence spectram and d) taucplot

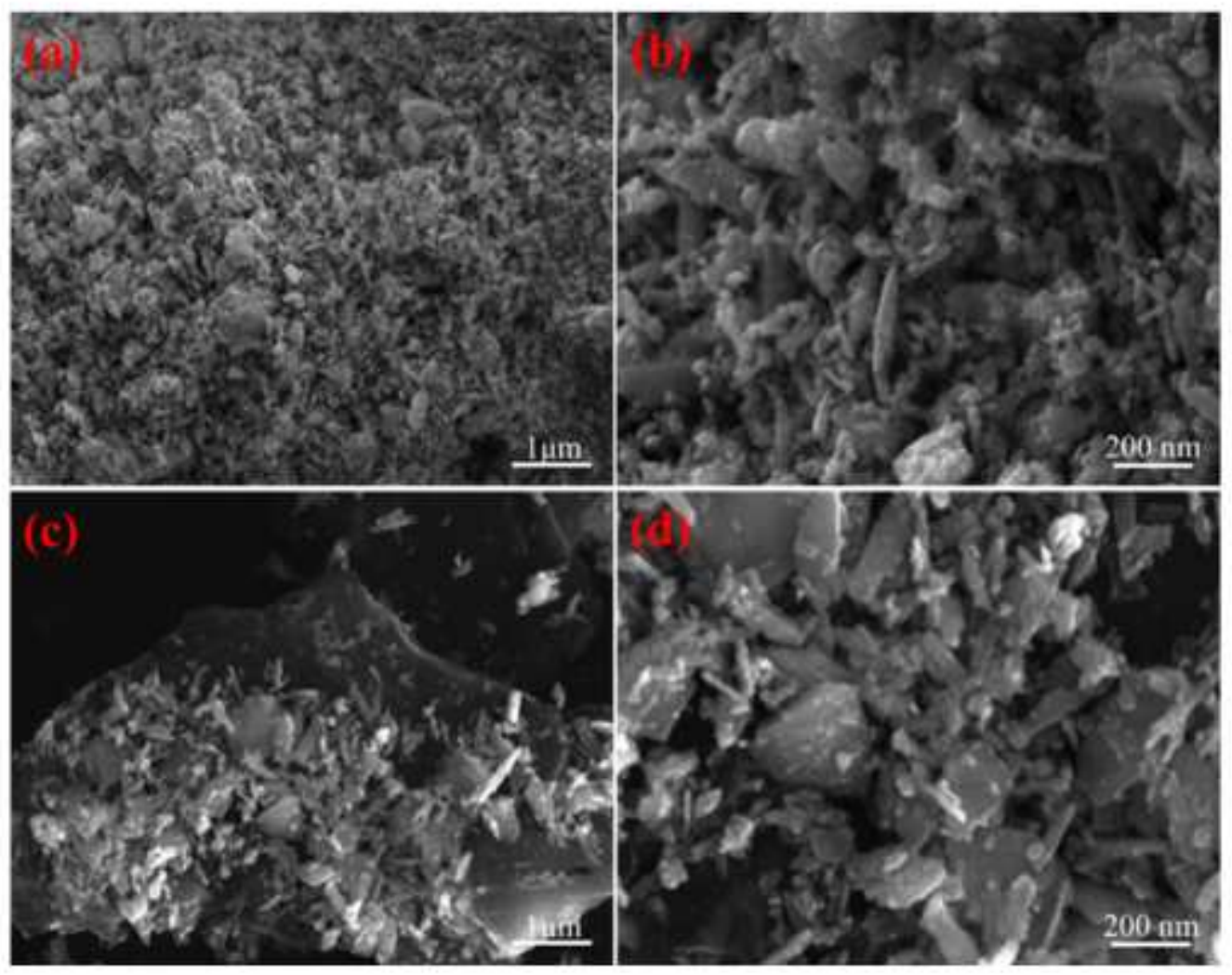

Figure 5

SEM images:a,b) CuZnWO4 and c,d) CuZnWO4-rGO low and high magnificaation respectively 

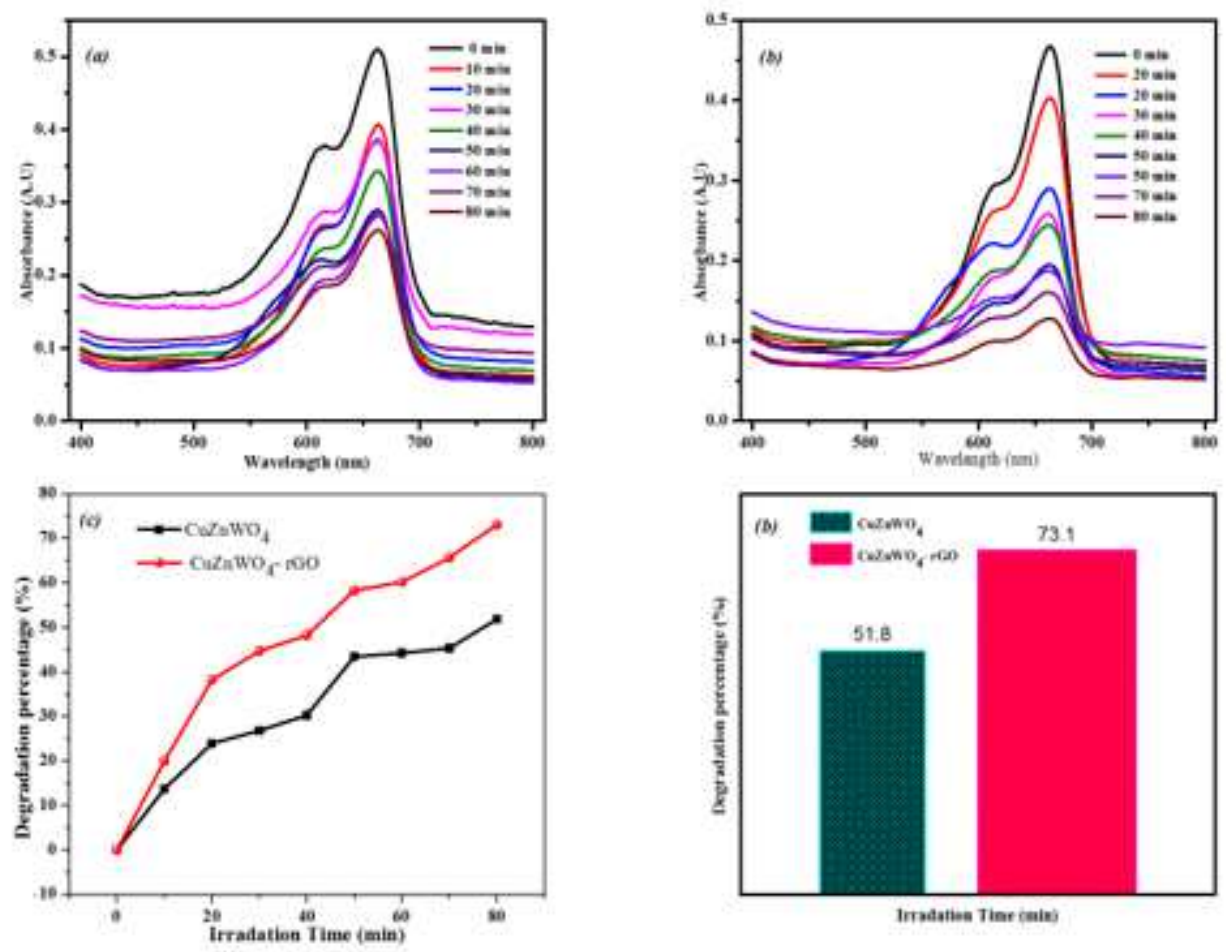

Figure 6

Photocatalytic dye degradation: a) CuZnWO4, b) CuZnWO4/rGO and c) Comparison of methylene blue degradation efficiency of CuZnWO4 andCuZnWO4/rGO under visible light
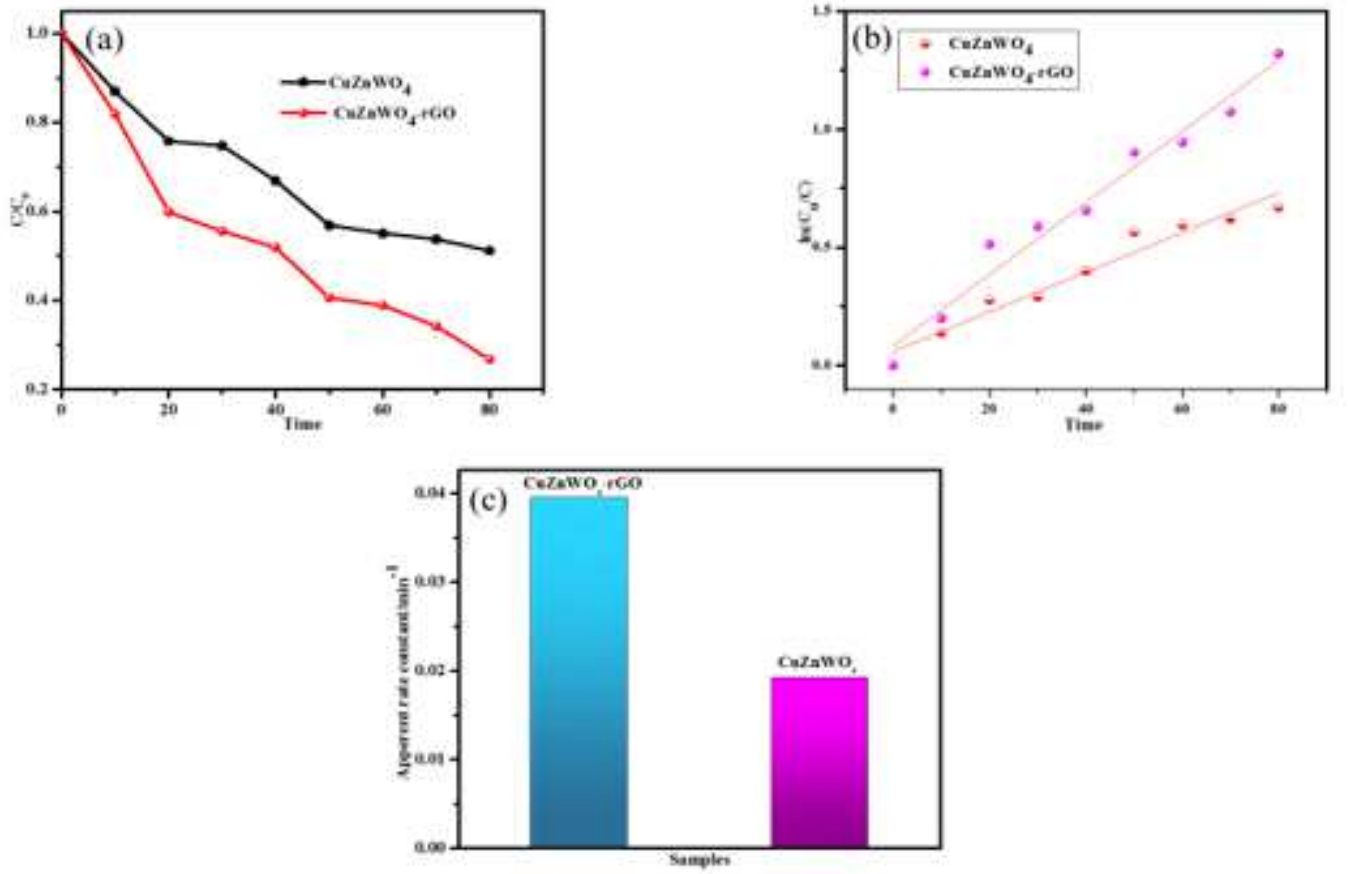

Figure 7 
Ln C/Covs. irradiation time for photocatalytic degradation of MB dye

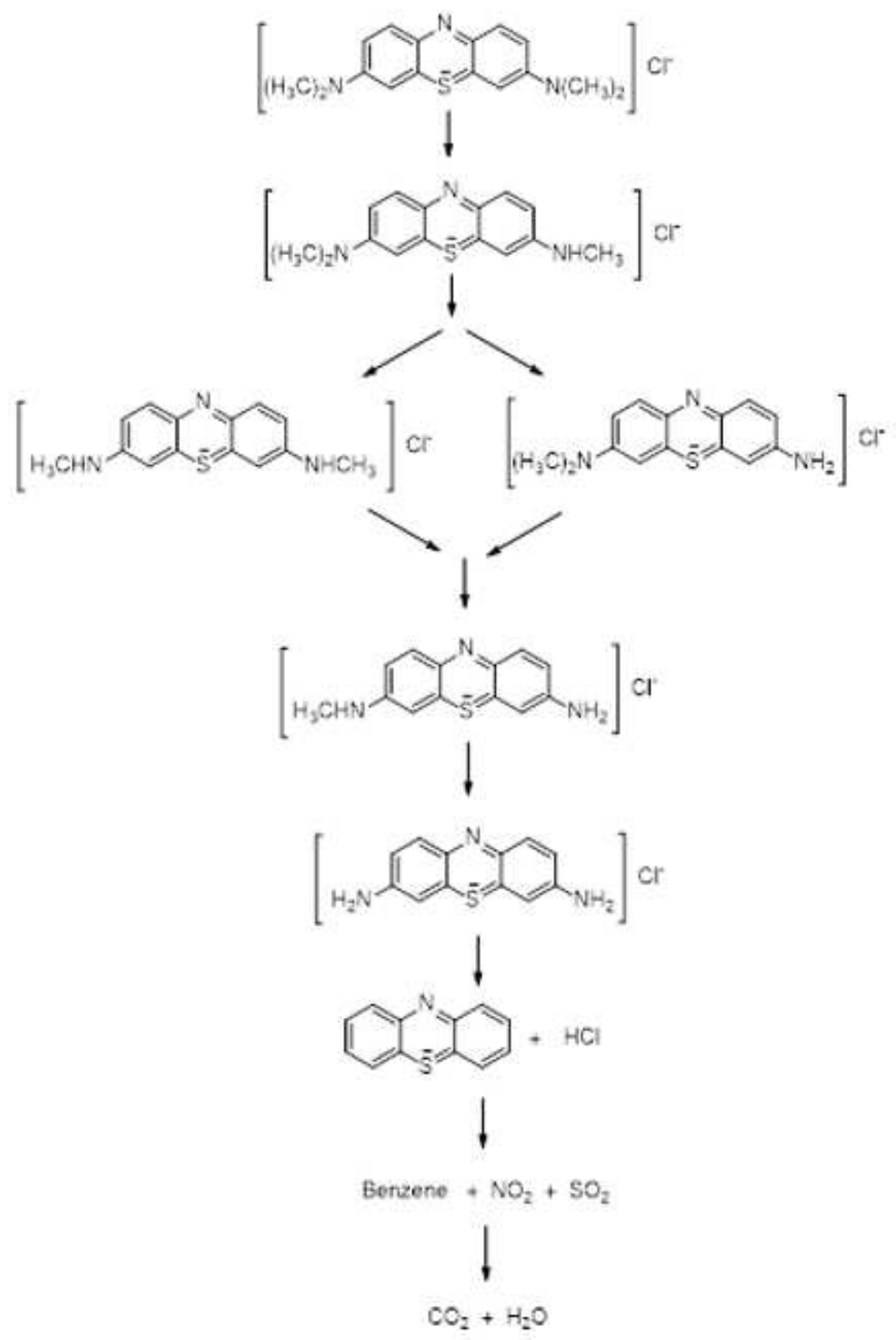

Figure 8

Mechanism of methylene blue dye degradation 

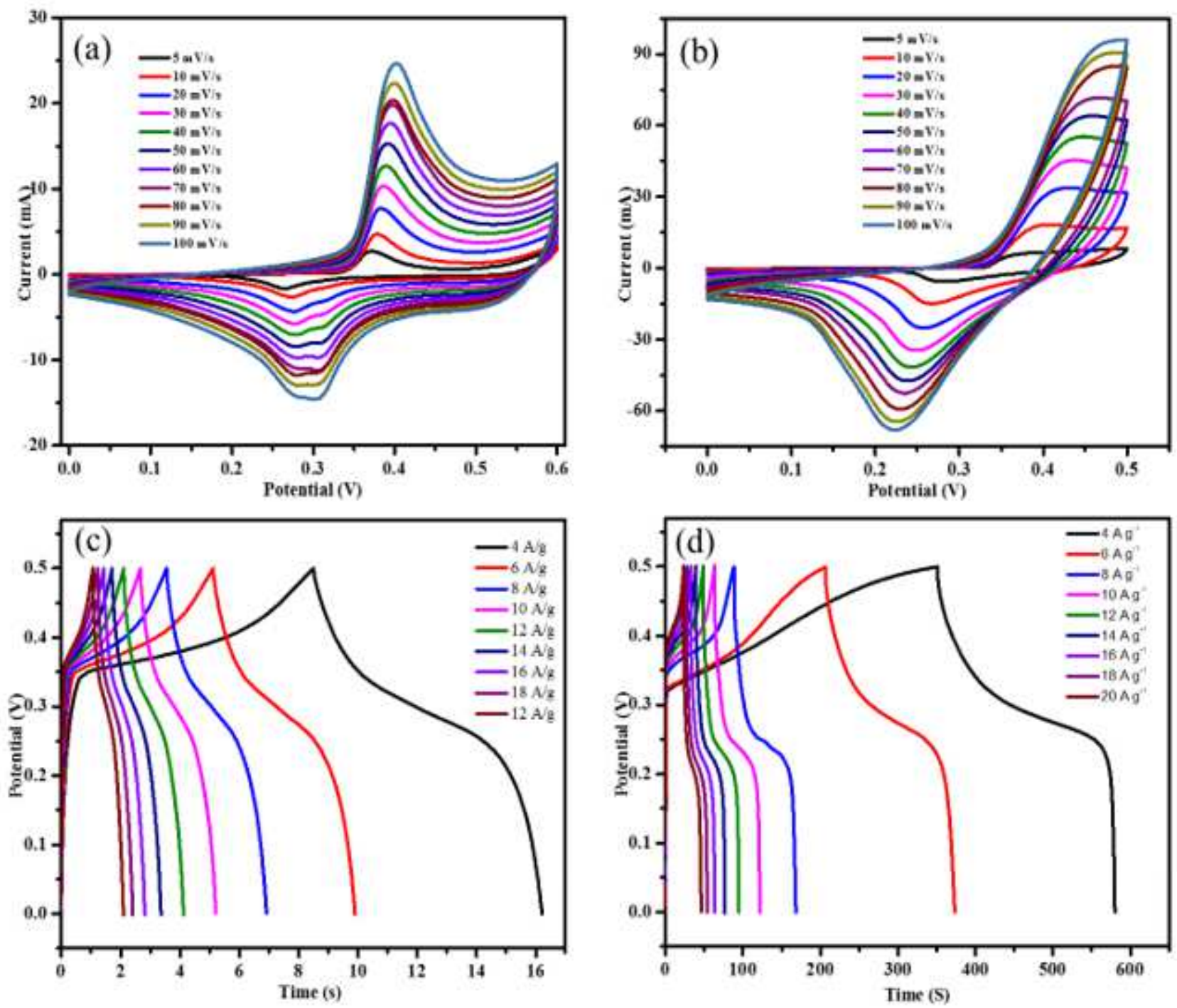

Figure 9

Cyclic voltammograms at various scan rates from 5 to 100 mV.s-1 a) CuZnWO4 and b) CuZnWO4/rGO, GCD at various current densities from 4 to $20 \mathrm{~A} . \mathrm{g}-1 \mathrm{c}$ ) CuZnWO4 and d) CuZnWO4. 

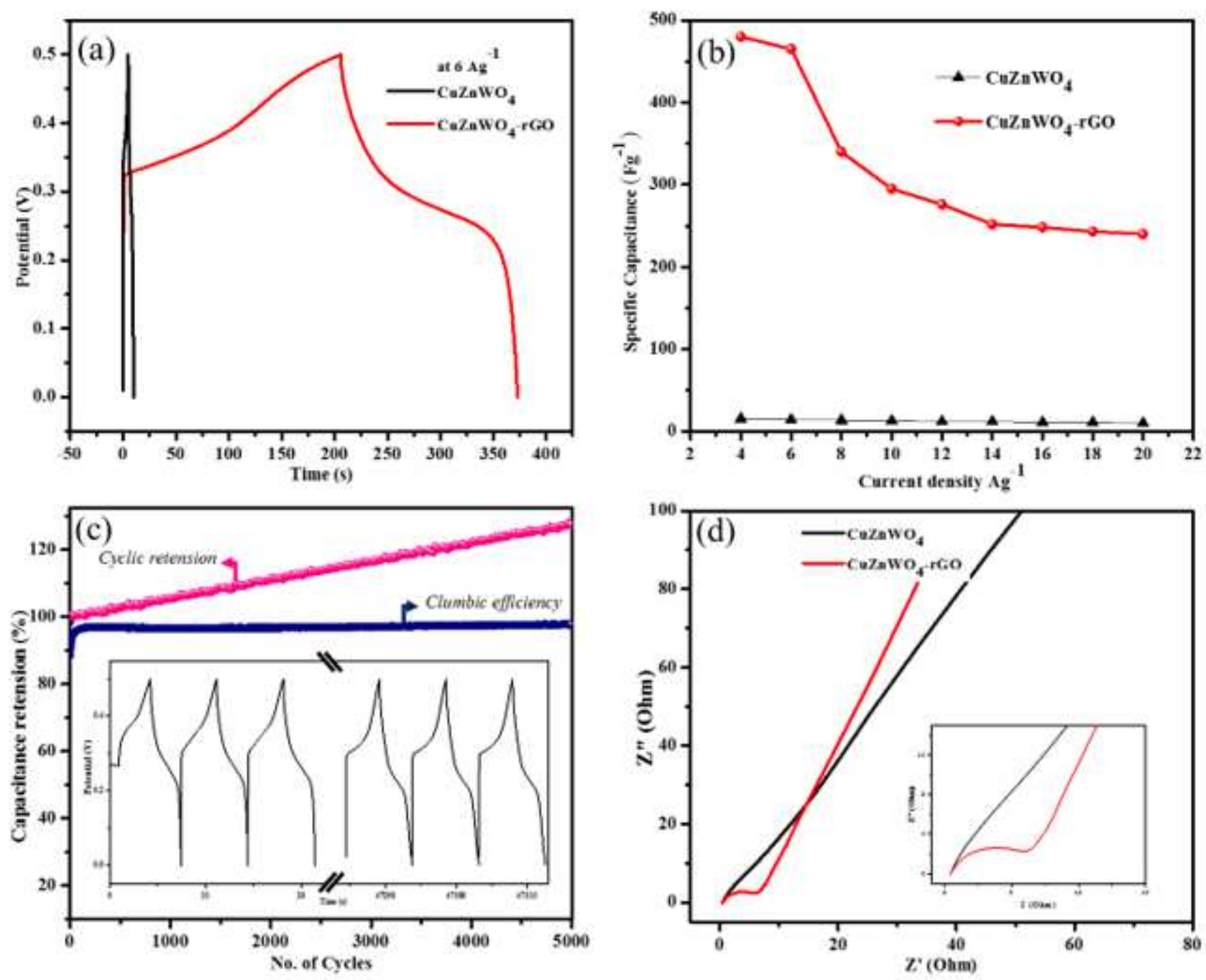

Figure 10

a) GCD comparison of CuZnWO4 and CuZnWO4/rGO at6 Ag-1, b)Comparison specific capacitance Vs current density c) Cyclability and culumbic efficiency ofCuZnWO4/rGO d) Nyquest plots 